\title{
ROMÁNSKÝ MEČ Z HOŠTIC NA KROMĚŘÍŽSKU
}

\author{
PETR ŽÁKOVSKÝ - JIŘÍ HOŠEK - PATRICK BÁRTA - ADAM FOJTÍK - MIROSLAV \\ POPELKA
}

\begin{abstract}
Abstrakt: Roku 2016 byl v rámci řizené systematické detektorové prospekce zalesněného území západního Kroměřžša učiněn solitérni nález románského meče. Zbran̆ lze klasifikovat jako meč typu XII, B, 1, a její výrobu klást do průběhu 12. století. Čepel je tvořena ocelovým pláštěm obalujicím měkči jádro, což byl $v$ dané době poměrně nový typ konstrukce, a na obou jejich stranách byla zjištěna specifická cínem inkrustovaná iniciálová inskripce, kterou lze nejspíše čist jako Salvator Iesus Omnipotens Salvator, respektive Omnipotens Salvator Iesus Omnipotens. Tyto i dalši detaily nálezu jsou v článku podrobně diskutovány.
\end{abstract}

Klíčová slova: meč - nápis - středověk - Hoštice-archeometalurgie.

\section{A Romanesque sword from Hoštice in the Kroměř̌̆ region}

Abstract: Systematic metal-detector prospection conducted in 2016 in the forested area of the western part of the Kromérizz region yielded a solitary find of a Romanesque sword. This weapon can be classified as a sword of the XII, B, 1 type, and its origin is sought in the 12th century. The blade consists of a layer of steel encasing a softer core, which was a relatively new type of construction used at the time. Besides, a specific tin-inlaid initial inscription was detected on both sides of the blade, which most likely reads as Salvator Iesus Omnipotens Salvator, or Omnipotens Salvator Iesus Omnipotens. These and further details of the find are in the article discussed in detail.

Key words: sword - inscription - Middle Ages - Hoštice - archaeometallurgy.

\section{Úvod}

V létě roku 2016 probíhala $\mathrm{v}$ rámci výzkumných aktivit Ústavu archeologické památkové péče (ÚAPP) Bno řízená systematická detektorová prospekce zalesněného území západního Kroměřižska, zaměřená mimo jiné i na monitorování historických komunikací v regionu. Při té př́ležitosti nalezl spolupracovník ÚAPP Martin Malý v poloze Světlová na katastrálním území obce Hoštice románský meč, který je předmětem předkládaného příspěvku. Zbraň byla uložena ve světlé lesní půdě v hloubce zhruba $30 \mathrm{~cm}$ od současné nivelety. Při jeho standardním odborném vypreparovávání nebyly zjištěny žádné stopy po záměrném vkopu, které by mohly naznačovat úmyslné uložení meče do země (obr. 1). Systematickou následnou prospekcí v bezprostředním okolí nálezu se nepodařilo získat žádné další artefakty, které by se studovanou zbraní mohly souviset. Bez zajímavosti není, že se nepodařilo nalézt ani zbytky pochvy či jiného obalu. Z těchto důvodů se musíme spokojit s interpretací nálezu jakožto náhodné ztráty související s využíváním komunikačních koridorů procházejících místem nálezu ve směru severovýchod-jihozápad. Ostatně svazky úvozových cest jsou dodnes na lidarových snímcích velmi dobře čitelné (obr. 2).

Meč byl nalezen v oblasti poměrně bohaté na archeologické památky, díky čemuž byla tomuto regionu věnována zvýšená pozornost již v minulosti (např. Skutil 1941; Fišer 1976). Dominují v něm především pravěké a protohistorické lokality a památky. Raně středověké osídlení je doloženo rovněž, ale jen sporadicky. Do období 9. století lze klást birituální pohřebiště ze Slížan, které bylo objeveno v první polovině 20. století v prostoru cihelny J. Navrátila (Skutil 1941, 23-24; Dostál 1966, 165). Patrně z hrobových celků pochází také nálezy keramických a železných artefaktů z blíže nespecifikované polohy v Troubkách (Dostál 1966, 184). Z období 9. až poloviny 10. století pochází pohřebiště v Litenčicích, které bylo objeveno v poloze Obecniny. První zmínky o lokalitě spadají již do konce 19. století, přičemž k vlastnímu výzkumu došlo až v druhé polovině 80. let 20. století (Chybová 1989, 63; 1990, 60; 1993, 77-78). Nejmladší z pohřebišt' představuje naleziště v poloze Smrchov ve Zborovicích. Počátky pohřbívání spadají již do období 8. a 9. století, přičemž jeho hlavní část je tvořena řadovým pohřebištěm, jehož existenci 


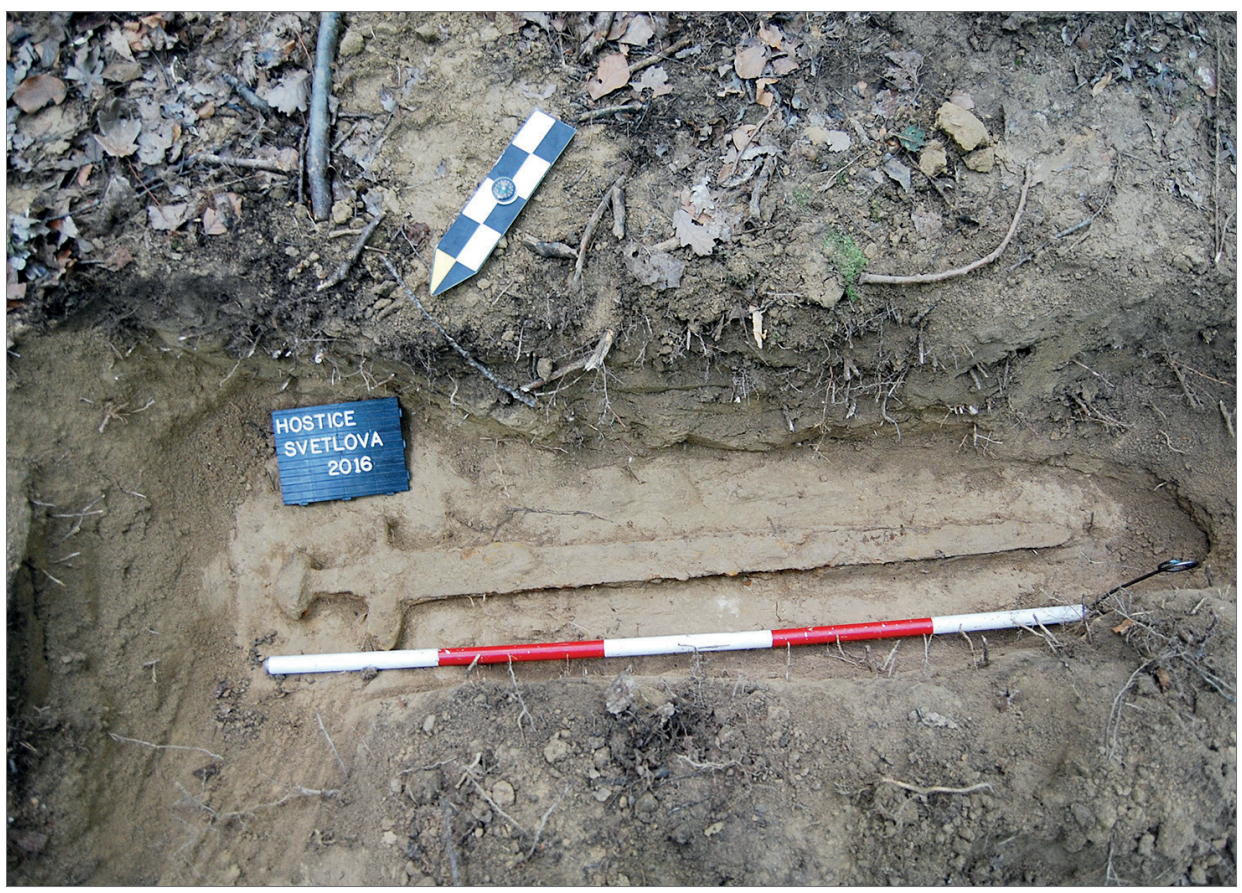

Obr. 1. Nález meče in situ před konečným vypreparováním.

Abb. 1. Fund des Schwertes in situ vor endgültiger Präparierung.

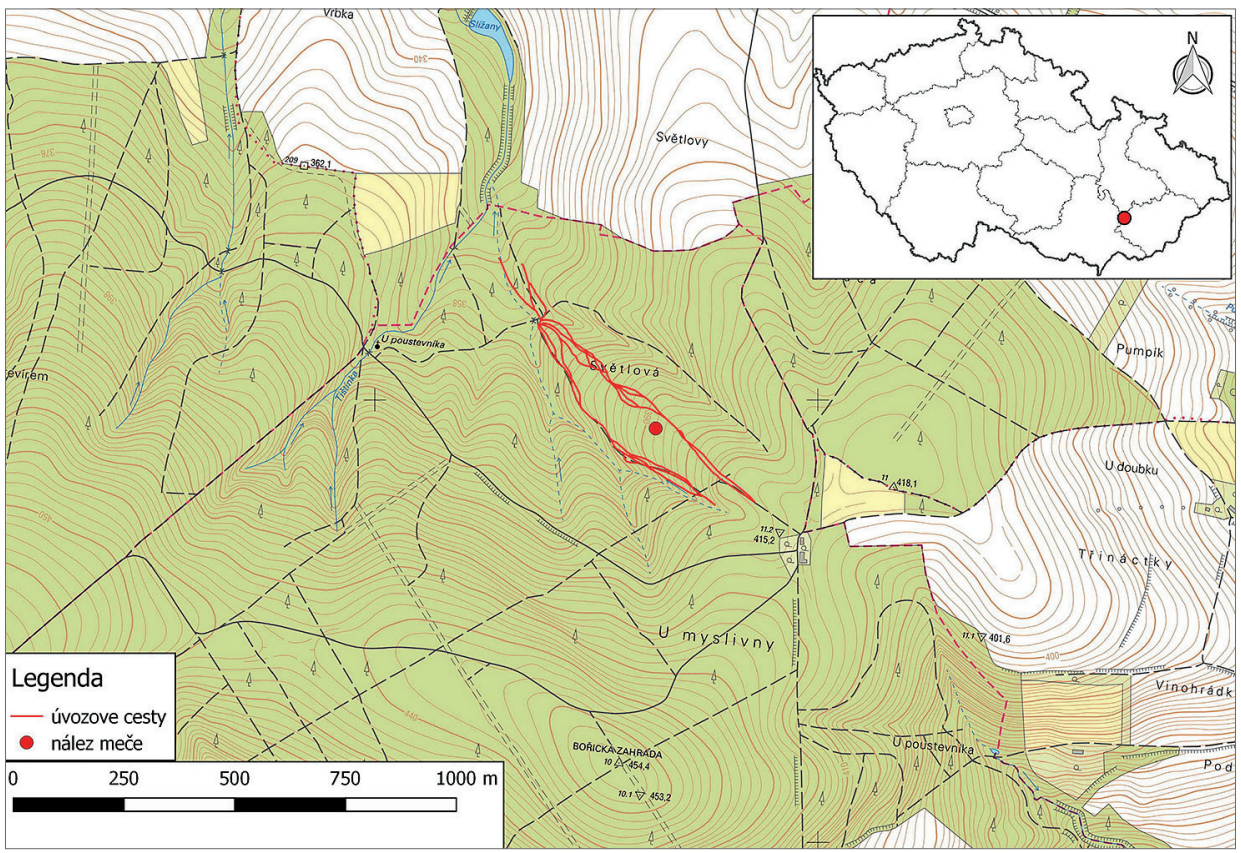

Obr. 2. Místo nálezu meče s vyznačeným patrným průběhem zaniklých komunikací.

Abb. 2. Fundort des Schwertes mit eingezeichnetem offenbaren Verlauf der verschwundenen Verkehrswege. 
lze na základě nálezů mincí klást do 11. století. Samotné pohřebiště je možné spojovat se sídlištěm v trati Podvláčí, které je známo z povrchových sběrů (Chybová 1986, 19-20; 1998, 131-132).

Následující období přináší již první písemné prameny, kterých lze ke sledování vývoje osídlení a majetkových vztahů v oblasti využít. Nejstarší písemné zmínky o obcích v regionu spadají do první poloviny 12. století, kam lze rámcově datovat i výrobu studovaného meče. $Z$ tohoto období, konkrétně z roku 1131, jsou historicky známé obce Litenčice a Hoštice (Hosák 1938, 386, 396; 1967, 186, 189; Hosák-Šrámek 1970, 283, 540). V případě Hoštic však není jisté, zda se daná zmínka neváže k Hošticím na Vyškovsku (Hosák-Šrámek 1970, 283). Pokud by tomu tak bylo, pak by první písemná zmínka o Hošticích ze západního Kroměřížska spadala až do první poloviny 14. století. Ze 13. století pochází zprávy o dalších dvou obcích - Morkovicích a Troubkách (Peřinka 1910, 204-205, 365-366; Hosák 1938, 380, 391; 1967, 185; Hosák-Šrámek 1980, 97, 604). Zbylé vsi jsou zmiňovány až v období kolem poloviny 14. století (Hosák-Šrámek 1980).

Ze zájmového prostoru je známo taktéž několik tvrzí, a to jak z pramenů historických, tak archeologických. Jako nejstarší lze na základě dosavadního bádání označit tvrz v Morkovicích, o níž se první písemná zpráva zmiňuje sice až k roku 1355, ale M. Plaček její možný původ klade již do 13. století (Nekuda-Unger 1981, 199; Plaček 2001, 409). Snad do 14. století je možné datovat tvrz Svárov u Hoštic (Červinka 1927, 92-93; Nekuda-Unger 1981, 277). Zbylé tvrze již spadají do období 15. až 16. století (Hosák 1938, 397; 1967, 189; Hosák-Šrámek 1970; 1980; Plaček 2001).

V širši oblasti nálezu je registrováno také několik zaniklých vsí, byt' u mnohých dodnes není známa jejich přesná lokalizace. S prostorem našeho zájmu je možné spojit čtyři takové vsi. Ty jsou v písemných pramenech poprvé zmiňovány ve druhé polovině 14. století, ale již v průběhu 15. století zanikly. Jednou z nich byly Opatovice lokalizované u Opatovského lesa u Morkovic (Peřinka 1910, 223-224; Červinka 1929, 153-155; Hosák 1938, 382; 1967, 185; Nekuda 1961, 67). Další zaniklou vsí je Skavsko, které se nacházelo v prostoru mezi Morkovicemi a Litenčicemi a jehož reliktem je dnešní dvůr stejného jména (Peřinka 1910, 223-224; Hosák 1938, 382; 1967, 185; Nekuda 1961, 80). Ves Svárov ležela v místech dvora u Hoštic, přičemž první zmínka o této vsi je až z roku 1381 (Peřinka 1910, 142-143; Hosák 1938, 397; 1967, 189; Nekuda 1961, 80). S touto obcí souvisí také zaniklá tvrz, o níž jsme se zmínili výše. Počátky tohoto opevněného sídla lze patrně klást nejspíše rovněž do druhé poloviny 13. století. V západním prostoru zájmového území je pak lokalizována zaniklá ves Šváby či Švábsko, jejíž poloha se nachází jižně od Pornic v místě dnešní hájovny (Peřinka 1910, 293-294; Červinka 1929, 153-155; Hosák 1938, 383-384; 1967, 186; Nekuda 191, 80).

Přestože tato zájmová oblast byla poměrně výrazně osídlena v průběhu starších dějin, poznatky o vývoji osídlení v průběhu 11. až 13 století, tedy v období, které nás eminentně zajímá, jsou prozatím nedostatečné. Tento stav je dán zejména dosavadní úrovní archeologického bádání, které se opírá především o starší nálezy, mnohdy pocházející pouze z povrchových sběrů bez řádné dokumentace. Na druhé straně sledovaný prostor skýtá možnost budoucího výzkumu, jehož výsledky mohou doplnit dosavadní archeologické i historické prameny a k poznání vývoje tamního osídlení přispět. To ostatně dokazuje i nález studované zbraně.

\section{Popis meče}

Jedná se o takřka kompletně dochovaný krátký meč o celkové délce 1009 mm, jehož hmotnost po konzervaci dosahuje $1102 \mathrm{~g}$. $^{1}$ Těžiště zbraně bylo naměřeno na čepeli ve vzdálenosti $165 \mathrm{~mm}$ od spodní hrany záštity. Jelikož zbraň byla ke konzervaci předána v nálezovém stavu, lze s jistotou říci, že v korozních produktech se nezachovaly žádné organické zbytky obložení rukojeti či př́ípadné pochvy (obr. 3,4$)$.

$1 \mathrm{~V}$ souborném díle věnovaném nálezům mečů z České republiky nalezne čtenár̆ poněkud rozdílný slovní popis studované zbraně, nebot' ta byla v té době dostupná jen v nálezovém stavu (Hošek-Košta-Žákovský 2019, 108-109, kat. č. 61). 


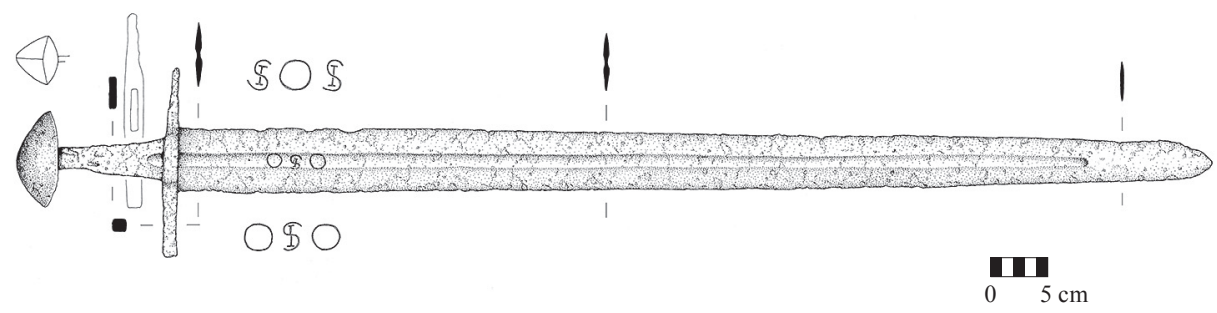

Obr. 3. Meč z Hoštic.

Abb. 3. Das Schwert von Hoštice.
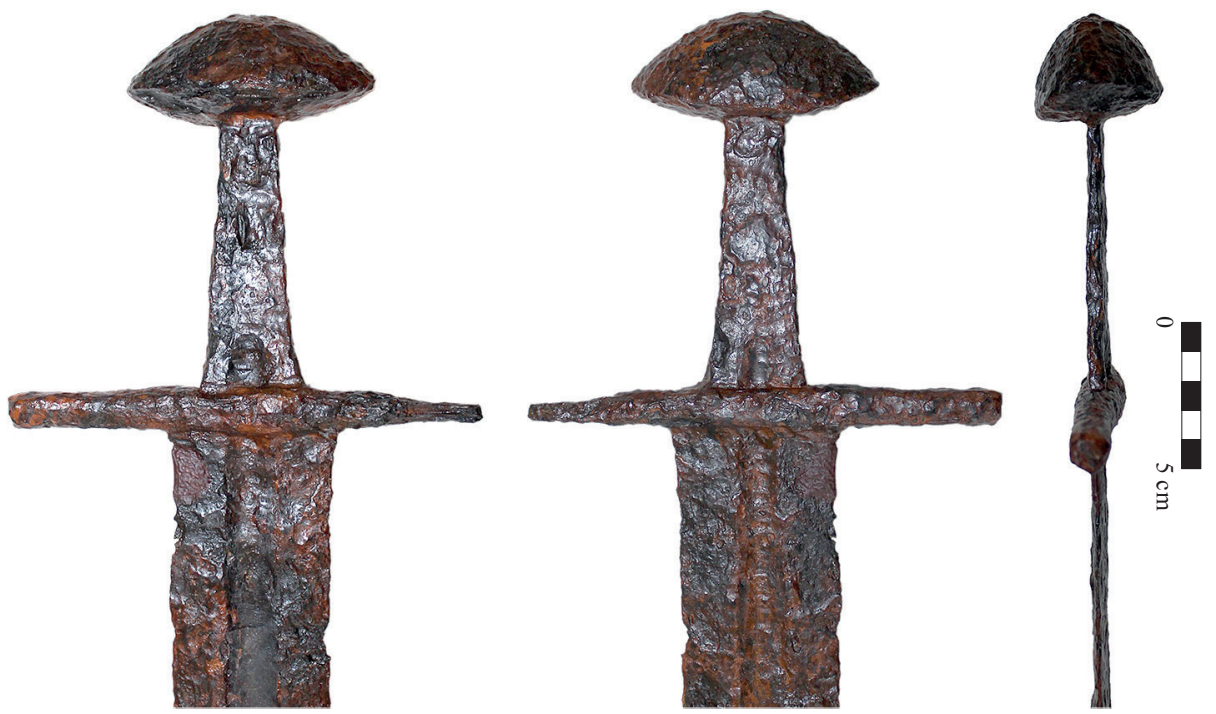

Obr. 4. Detail garnitury rukojeti meče z Hoštic.

Abb. 4. Gefäßdetail des Schwertes von Hoštice.

Zbraň je vybavena $867 \mathrm{~mm}$ dlouhou, poměrně plochou obousečnou čepelí, jejíž šířka se směrem k hrotu plynule parabolicky zužuje z $55 \mathrm{~mm}$ u záštity na $26 \mathrm{~mm}$, naměřených před začátkem vlastní hrotové partie. Ta je tvořena poměrně širokým hrotitým obloukem, který vytváŕí nevýrazný hrot čepele. Partie tenčí čepele je výrazně poškozena korozí. Tloušt'ka čepele se směrem k hrotu rovněž plynule zužuje z původních 5 na $2 \mathrm{~mm}$. Čepel je po obou stranách opatřena poměrně hlubokým výrazně ohraničeným žlábkem, zabírajícím téměř třetinu šířky čepele, který začíná již na řapu zbraně a končí zhruba $10 \mathrm{~cm}$ od hrotu. Při rentgenovém průzkumu byly po obou stranách hrubí objeveny zbytky iniciálové inskripce. Ta na jedné ploše sestává z litery $O$, ligatury $S I$ a další litery $O$. Na druhé ploše z ligatury $S I$, litery $O$ a další ligatury SI. Analýzou prvkového složení bylo zjištěno, že jednotlivé litery byly inkrustovány cínem.

$\mathrm{Na}$ čepel navazuje oboustranně odsazený řap o délce $142 \mathrm{~mm}$, jehož šírka se směrem k hlavici plynule parabolicky zužuje z původních $34 \mathrm{~mm}$ naměřených u svrchní hrany záštity na $20 \mathrm{~mm}$ pod spodní hranou hlavice. Obdobně klesá i jeho tloušt'ka ze 7 na $5 \mathrm{~mm}$. Ve spodní části řapu jsou po obou jeho plochách zřetelně viditelné počátky žlábku čepele. Po odečtení šiřrky 
záštity, respektive jejího ecussonu, která činí $16 \mathrm{~mm}$, a délky hlavice $35 \mathrm{~mm}$ od celkové délky řapu dostaneme celkovou délku původní rukojeti, která činí $91 \mathrm{~mm}$.

$\mathrm{Na}$ řap byla navlečena záštita s př́mými rameny o celkovém rozpětí $160 \mathrm{~mm}$. Ramena záštity byla vyrobena z mírně hraněné železné tyčinky přibližně kvadratického průřezu se zkosenými až zaoblenými hranami. Šírka i tloušt'ka se směrem od ecussonu ke koncům ramen plynule zužují z 16 na $13 \mathrm{~mm}$. Maximální šířka i tloušt'ka nevýrazně vyvinutého ecussonu dosahuje $16 \mathrm{~mm}$. Jedno z ramen záštity je výrazně poškozeno korozí.

Poměrně masivní hlavice čočkovitého tvaru či tvaru paraořechu má výrazně konvexní spodní i svrchní hranu. Její maximální délka dosahuje $35 \mathrm{~mm}$, maximální šířka $81 \mathrm{~mm}$ a maximální tloušt'ka $43 \mathrm{~mm}$. U svrchní hrany pak tloušt'ka dosahuje $5 \mathrm{~mm}$. Maximální šířka i tloušt'ka hlavice jsou situovány zhruba v polovině její celkové délky. Násadní otvor procházející celou hlavicí je na spodní ploše nebývale zvětšen a má čtvercový tvar. Na svrchní ploše hlavice jsou patrné zbytky roznýtovaného konce řapu.

\section{Typologicko-chronologická analýza meče}

\section{Garnitura rukojeti}

Na základě charakteristických markantů lze meč přiřadit k poměrně hojně zastoupené skupině románských mečů, pro které je signifikantní využití různých variant masivních hlavic čočkovitého tvaru, rovných záštit a poměrně dlouhých a plochých čepelí, opatřených zpravidla různě dlouhými žlábky. Tuto poměrně početnou skupinu mečů poněkud překvapivě nedefinoval E. Oakeshott při vytváření svých „sword families“, které asi nejvýstižněji charakterizují tvarovou a typovou škálu garnitur rukojetí vrcholně středověkých mečủ (Oakeshott 2002, 11-13).

Hoštický meč byl vybaven záštitou s př́imými rameny kruhového, místy až oválného průřezu. Ecusson záštity byl utvořen jejím prostým zesílením, což výrobci dovolilo bezrizikové proražení obdélného násadního otvoru. Záštitu lze jednoznačně přiřadit $\mathrm{k}$ typu 1 , který byl v průběhu celého středověku i raného novověku typem nejběžnějším (např. Oakeshott 1964, 113).

Řap zbraně má plochý obdélný průřrez a jen ve spodní části je patrný počátek žlábku čepele. Šíŕka řapu se směrem k hlavici poměrně výrazně parabolicky zužuje. Původní délka rukojeti dosahovala pouhých $99 \mathrm{~mm}$, což dovolovalo vcelku pohodlný úchop zbraně jednou rukou. Celkový tvar i rozměry hlavice však téměř znemožňovaly př́ípadný obouruční úchop meče.

Hrany poměrně masivní hlavice čočkovitého tvaru totiž svírají poměrně ostrý úhel. Tento detail je typický zejména pro hlavice typu A, které se na mečích objevují v poměrně dlouhém časovém úseku od poloviny 10. do 12. století (např. Oakeshott 1951; 1964, 93). Tyto hlavice mají sice z čelního pohledu velmi podobný tvar jako hlavice meče z Hoštic, ovšem na rozdíl od ní jsou podstatně plošší a jejich čelní plochy nejsou tak výrazně konvexní. Studovaná hlavice je totiž v bokoryse výrazně objemnější a v profilu zakulacenější (obr. 4, 5). Tím se spíše hlásí $\mathrm{k}$ hlavicím typu B, pro které jsou tyto specifikace charakteristické. Různé varianty hlavic typu B patří obecně k nejrozšířenějším tvarům hlavic v průběhu dlouhého časového úseku zabírajícího druhou polovinu 11. až polovinu 13. století, přičemž se zatím nepodařilo spolehlivě prokázat, zda mezi jednotlivými tvarovými variantami existuje př́ípadná chronologická návaznost, či se všechny tyto tvary objevují současně. Pro meče s daným typem hlavice je charakteristické především využití čepelí

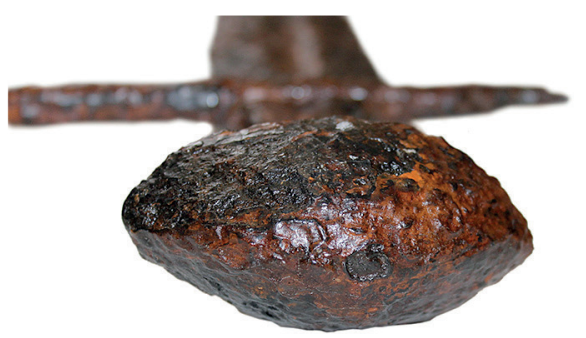

Obr. 5. Svrchní pohled na hlavici meče z Hoštic s patrnou roznýtovanou závěrnou hlavou řapu.

Abb. 5. Oberansicht des Knaufs des Schwertes von Hoštice mit erkennbarem entnieteten abschließenden Griffkopf. 
typu X, Xa, XI a ve větší míře i čepelí typu XII. Doprovází je takřka výhradně prosté záštity s př́mými rameny typu 1 (napr. Oakeshott 1951; 1964, 93; Geibig 1991, 65-68; Pinter 2007, 132-133, tab. 32; Aleksić 2007, 35-37; Kucypera-Kurasiński-Pudło 2011; Michalak 2018).

Této charakteristice zcela odpovídá i materiál prozatím získaný z území České republiky. Dosud máme k dispozici celkem jedenáct exemplářu hlavic, které lze přiřadit ke studovanému typu, z nichž jeden kus představuje solitérní nález hlavice (Hošek-Košta-Žákovský 2019, kat. č. 345) a jeden kus torza meče, jehož čepel nelze blíže klasifikovat (Hošek-Košta-Žákovský 2019, kat. č. 304). Jedním exemplářem je zastoupen meč s čepelí typu Xa nesoucí na čepeli značku v podobě berličkového kříže a torza liter, ze kterých je patrné jen písmeno $S$ (obr. 14:d; Hošek-KoštaŽákovský 2019, kat. č. 299). Dva z mečů jsou opatřeny čepelí typu XI (Hošek-Košta-Žákovský 2019, kat. č. 189, 382), jeden z nich nese na čepeli zbytky litery $O$. S jistými výhradami pak lze další čepel z mečů vybavených hlavicí typu B přiřadit k typu XIa (Hošek-Košta-Žákovský 2019, kat. č. 408). Ostatní zbraně, tedy celkem čtyři exempláře, lze přiřadit k mečům s čepelí typu XII. Kromě studovaného meče z Hoštic se jedná o čepel meče z Hradce Králové, jež je opatřena inskripcemi $O O O$ a III (Hošek-Košta-Žákovský 2019, kat. č. 63). Další zbraň z Petroviček (Hošek-Košta-Žákovský 2019, kat. č. 173) a blíže nelokalizovaný meč ze sbírek Národního muzea v Praze (Hošek-Košta-Žákovský 2019, kat. č. 372) jsou bez viditelných značek a inskripcí.

Zvláštní místo mezi hlavicemi daného typu představuje exemplář z blíže nelokalizované zbraně z bývalé fürstenberské sbírky na Křivoklátě. Hlavice typu B zde totiž byla v průběhu druhé poloviny 14. až první poloviny 15 . století nepochybně druhotně využita při konstrukci dlouhého meče s čepelí typu XVIa (Głosek 1984, 142, kat. č. 61, tab. XXXIII:1; Hošek-Košta-Žákovský 2019, kat. č. 324). Zda byla hlavice pro majitele zbraně důležitá jako určitá memorabilie, a proto jí záměrně nechal osadit svoji novou zbraň, či se na meč dostala zcela náhodně, se však již nedozvíme. ${ }^{2}$

Obecně lze říci, že hlavice typu B se objevují na vcelku jednotné skupině mečů, které mimo velmi podobný tvar spojuje i velmi obdobná skupina inskripcí s prevahou liter S, O a I, které se objevují na celé řadě mečů po celém území jejich rozšíření (např. Geibig 1991, 241; Aleksić 2007, 36; Gaspari 2017, kat. č. 47).

Pokud bychom chtěli zařadit garnituru rukojeti našeho meče do podrobného typologického systému A. Geibiga, zvolili bychom nejspíše jeho kombinační typ 16-I (16-15-10-13), který v podstatě v základních rysech koresponduje s výše uvedenými zjištěními (Geibig 1991, 70-73, obr. 17).

\section{Čepel}

Asi nejvíce se čepel hoštického meče blíží čepelím typu XII podle E. Oakeshotta, které jsou v základních rysech poměrně široké, ploché a parabolicky se zužující směrem k poměrně nevýraznému hrotu. Většinou bývají opatřeny žlábky ukončenými nejčastěji ve dvou třetinách či třech čtvrtinách celkové délky čepele. Jejich datační rámec je poměrně široký, nebot' jejich výskyt je shledáván zhruba od poloviny 12. do poloviny 14. století (Oakeshott 1964, 37-41; Głosek-Nadolski 1970, 22-23; Głosek 1984, 28; Aleksić 2007, 82). V určitých detailech se však studovaná čepel od čepelí typu XII mírně odlišuje. Jedním z těchto detailů je délka žlábku, která na hoštickém meči dosahuje až téměř k samotnému hrotu. Také délka řapu, respektive rukojeti, je u studovaného meče o něco kratší než u klasických představitelů typu XII a jednoznačně spíše odkazuje na starší typy čepelí nereflektující př́ípadný progresivní vývojový trend, který se projevil v postupném prodlužování čepele i rukojeti ve spojitosti s formováním výrazně zahrocených hrotových partií čepelí. Dalo by se říci, že čepel meče z Hoštic stojí někde na pomezí mezi typy Xa a XII. V klasifikaci vytvořené A. Geibigem bychom studovanou čepel mohli přiřadit nejspíše k typu 10, pro který jsou charakteristické poměrně široké a dlouhé žlábky (Geibig 1991, 87-89, obr. 22). M. Aleksić

2 Ve sbírkách Fitzwilliam Museum v Cambridge je dnes chována velice podobná zbraň, kterou E. Oakeshott považoval za kompaktní výrobek z první poloviny 13. století (Oakeshott 2002, 223). Ani zde však nelze vyloučit možnost, že by se mohlo jednat o druhotné využití staršího typu hlavice na mladší čepeli. 
srovnal ve své vynikající práci sice čepele Oakeshottova typu XII s Geibigovým typem 12, ale ten má podle našeho mínění již více zahrocenou hrotovou partii (Aleksić 2007, 29).

Pokud, byt' s určitými výhradami, přijmeme klasifikaci čepele meče z Hoštic jako čepel typu XII, můžeme ji obecně zařadit k poměrně rozšířenému typu čepelí objevujících se zejména v průběhu 12.-13. století. O jejich oblibě svědčí zejména 56 exemplářů z oblasti stř̌ední Evropy, které tak kategorizoval ve své práci $M$. Głosek $(1984,28)$. V případě dosud evidovaného nálezového fondu středověkých mečů z území dnešní České republiky je však situace poněkud odlišná. K čepelím typu XII můžeme sice přiřadit dalších sedmnáct exemplářů, z nich ale pouze pět lze obecně datovat do průběhu 12. až první poloviny 13. století (Hošek-Košta-Žákovský 2019, kat. č. 63, 173, 297, 372 a 428). Je poměrně charakteristické, že v této nepočetné skupině mečů se uplatnila řada různých typů hlavic. Vedle hlavic čočkovitého tvaru typu B (Hošek-Košta-Žákovský 2019, kat. č. 63, 173 a 372) se objevují i masivní hlavice typu D a N (Hošek-Košta-Žákovský 2019, kat. č. 297 a 428). Ve všech př́ípadech jsou pak tyto meče opatřeny základním tvarem záštit s přímými rameny vyrobenými ze železné tyčinky bud' kvadratického, či kruhového a mírně oválného průřezu typu 1. Většinu mečů s čepelí typu XII z území České republiky lze však datovat až do průběhu druhé poloviny 13. až poloviny 14. století. Univerzálnost daného tvaru čepele $\mathrm{v}$ daném časovém období dosvědčuje především fakt, že při konstrukci těchto krátkých mečů se uplatnila poměrně široká škála typů záštit i hlavic, mezi nimiž se objevují především různé varianty jejich diskovitých forem (Hošek-Košta-Žákovský 2019, kat. č. 9, 64, 71, 77, 93, 94, 163, 197, 202, 335 a 399). Musíme mít ovšem na paměti, že typologická klasifikace čepelí je do značné míry subjektivní záležitostí, což o případné kategorizaci čepelí typu XII platí dvojnásob.

Čepel meče z Hoštic byla podrobena metalografickému průzkumu. Vzorek A byl odebrán z břitu čepele, ve vzdálenosti $14 \mathrm{~mm}$ od spodní hrany příčky, a vzorek B pak z hrotové části čepele, ve vzdálenosti $845 \mathrm{~mm}$ od spodní hrany př́íčky (obr. 6:a). ${ }^{3}$

Materiál vzorku A obsahuje na většině plochy menší až středně velké množství jemných i hrubších vměstků strusky (čistota kovu odpovídá stupni 2 až 3 dle normy Jernkontoret). Menší část plochy při pravé straně vzorku je velmi hustě prostoupena velice drobnými vměstky (čistota kovu odpovídá stupni 4 až 5 dle Jernkontoret). Po naleptání nitalem byla odhalená struktura rozdělena do tř́ oblastí (obr. 6:b). V oblasti I je popuštěný martenzit o tvrdosti $477 \pm 12$ HV0,2 (obr. 7:a). V oblasti II jsou feritická zrna provázená zrny perlitu až (převážně) popuštěného martenzitu (ferit zabírá zhruba $70 \%$ plochy). Struktura je jemnozrnná (ASTM 8-9), tvrdost dosahuje $190 \pm 10$ HV0,2. Oblast III je přechodovou zónou mezi oblastmi I a II, tj. nerovnoměrnou směsí zrn feritu a popuštěného martenzitu (obr. 7:b, c). Leptání vzorku Oberhofferovým činidlem zviditelnilo svarové linie související s konstrukcí čepele (obr. 7:d, e). Je zřejmé, že oblasti II a III jsou součástí jádra, zatímco většina oblasti I náleží vnějšímu plášti.

Materiál vzorku B obsahuje menší množství velmi drobných struskových vměstků. Čistota kovu odpovídá stupni 2 dle normy Jernkontoret. Po naleptání nitalem lze vymezit dvě vzájemně si dosti podobné strukturní oblasti (obr. 6:b). V oblasti I.a je struktura popuštěného martenzitu o tvrdosti $489 \pm 21$ HV0,2, v oblasti I.b je rovněž popuštěný martenzit, avšak o nižším obsahu uhlíku a tím i o nižší tvrdosti $396 \pm 29$ HV0,2 (obr. 7:f). Po naleptání Oberhofferovým roztokem je mezi oběma oblastmi rozpoznatelná tenká svarová linie. Zda souvisí s konstrukcí, či přípravou ocelového polotovaru, nelze rozhodnout.

Z technologického hlediska se tak jedná o čepel s ocelovým pláštěm obalujícím jádro, jehož přesnou povahu nelze ze vzorku určit. Zachycená část jádra nasvěděuje svaření z více částí a sestává z ocelí s nižším i vyšším obsahem uhlíku. Čepel byla v celém svém objemu kalena a popuštěna.

3 Vzorky pro metalografickou analýzu byly z čepelí odebrány pomocí mikrobrusky a dále připraveny standardními postupy (zality do dentakrylu, za mokra vybroušeny na sadě brusných papírů, doleštěny pomocí diamantových past). Hodnoceny byly ve stavu neleptaném (sledována vměstkovitost a svarové linie), dále po naleptání 3\% nitalem (charakter a rozložení základních struktur) a Oberhofferovým roztokem (sledovány svarové linie a rozložení fosforem bohatších a chudších částí). Čistota kovu byla podle tradice laboratoře ARÚ Praha hodnocena normou Jernkontoret, velikost zrn normou ASTM E112. Struktura byla pozorována a dokumentována na mikroskopu Olympus BX $60 \mathrm{~s}$ digitálním záznamem obrazu pomocí fotoaparátu Olympus E-450. Tvrdost byla změřena Vickersovou metodou na tvrdoměru Wilson Wolpert 401MVD při zatížení $0,2 \mathrm{~kg}$. 

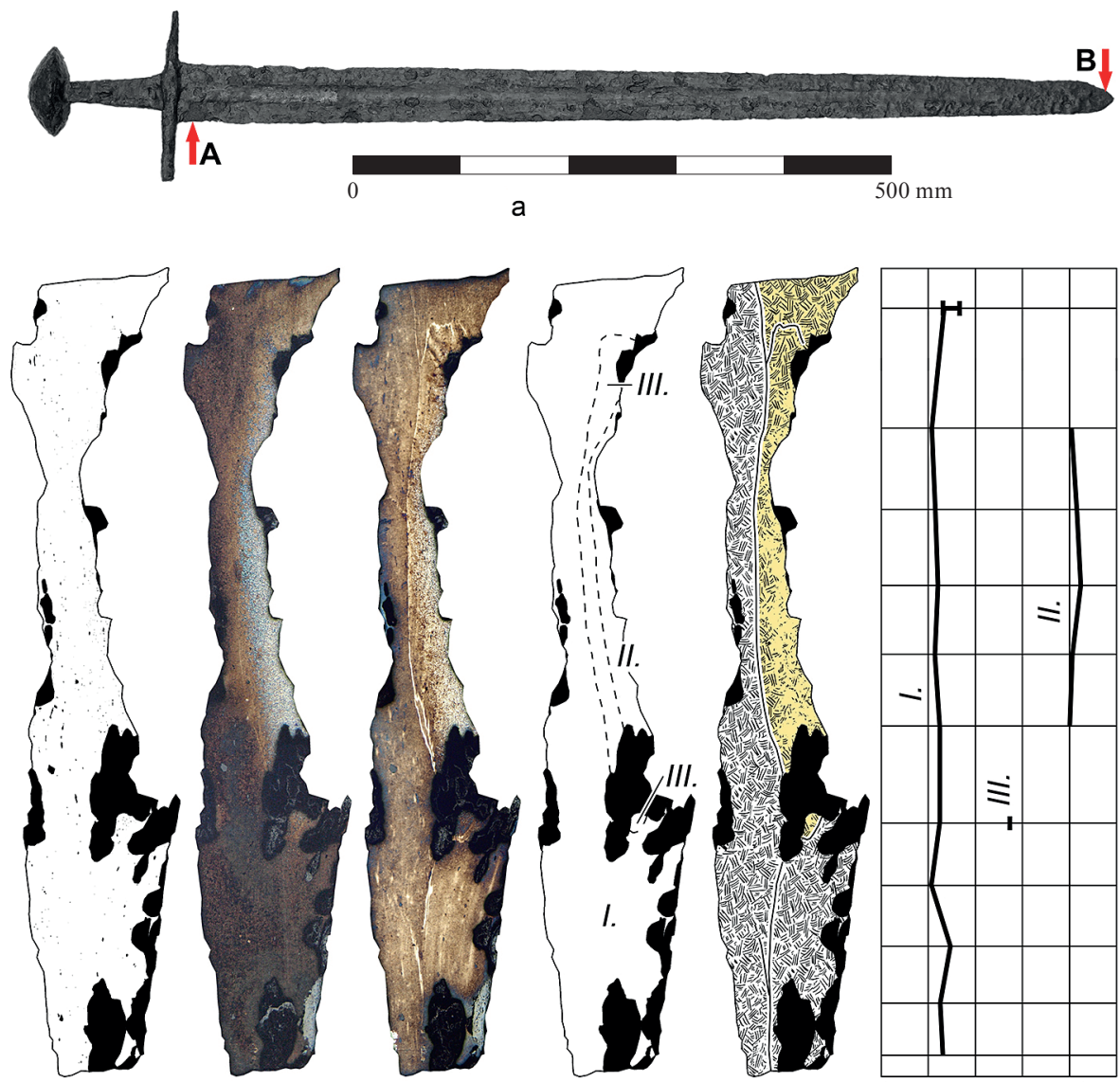
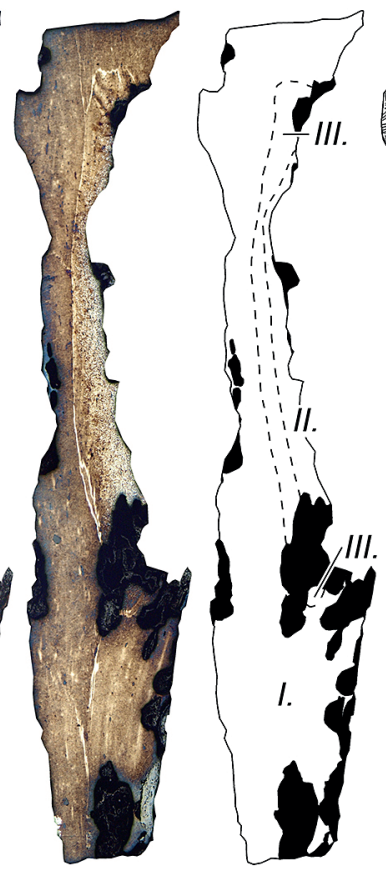

A

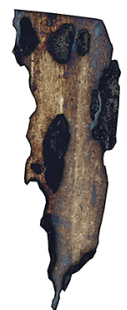

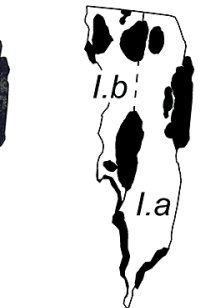

B
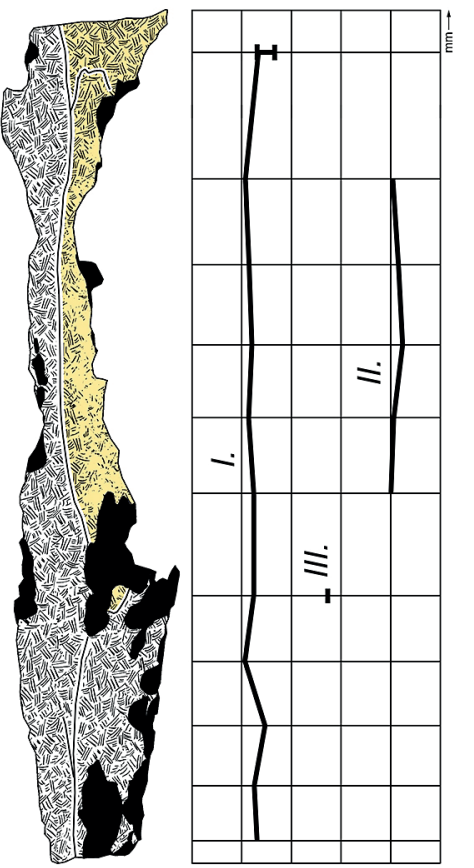
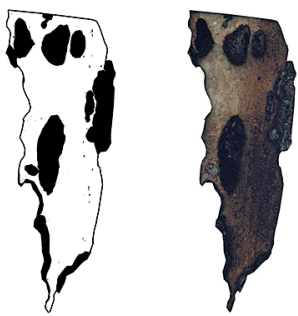
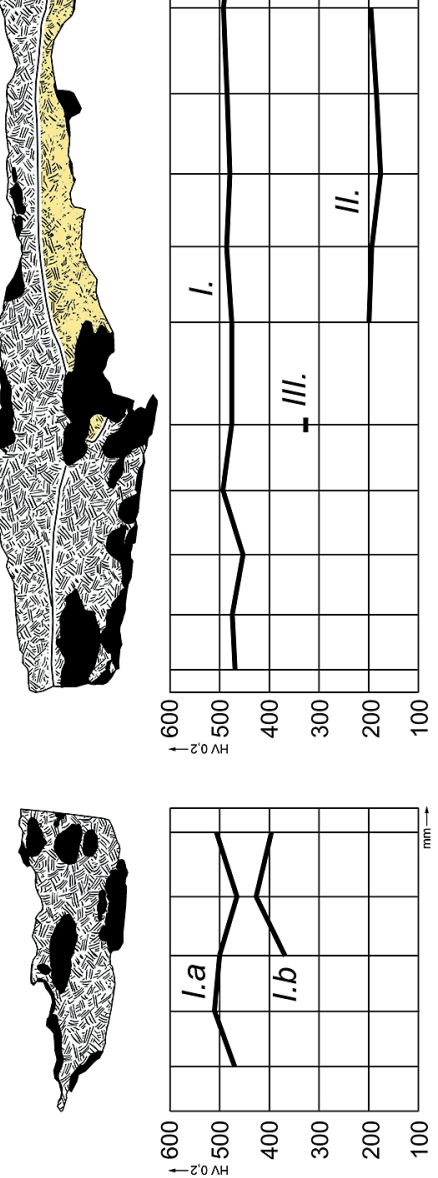

Obr. 6. Meč z Hoštic. a-studovaný meč a způsob jeho navzorkování; b-schematické nákresy a makrofotografie vzorků A a B zleva: neleptaný stav, po naleptání nitalem, po naleptání Oberhofferem, rozložení popisovaných strukturních oblastí, vyznačení hlavních svarů a zachycených strukturních oblastí, graf průběhu tvrdosti. Žlutě vymezená oblast odpovídá jádru čepele.

Abb. 6. Schwert von Hoštice. a - untersuchtes Schwert und Art und Weise seiner Untersuchung; b-schematische Zeichnungen und Makrofoto der Proben A und B - von links: ungeätzter Zustand, nach Ätzung mit Nital, nach Oberhoffer Ätzung, Zersetzung der beschriebenen Strukturbereiche, Kennzeichnung der Hauptschweißnähte und erfassten Strukturbereiche, Diagramm des Härteverlaufs. Gelb - der eingegrenzte Bereich entspricht dem Klingenkern. 

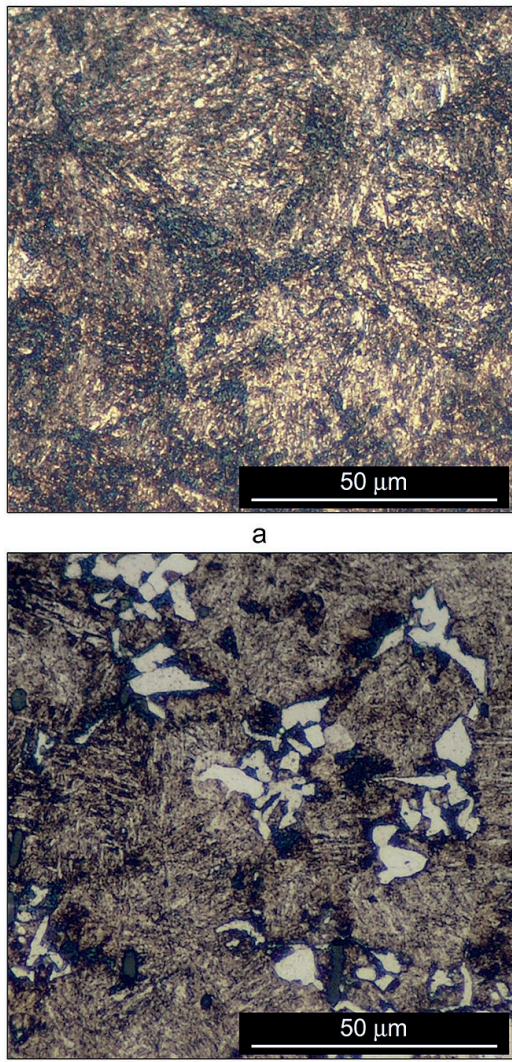

C

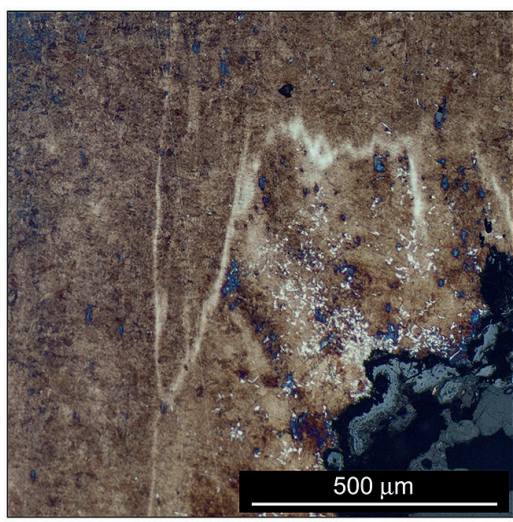

e

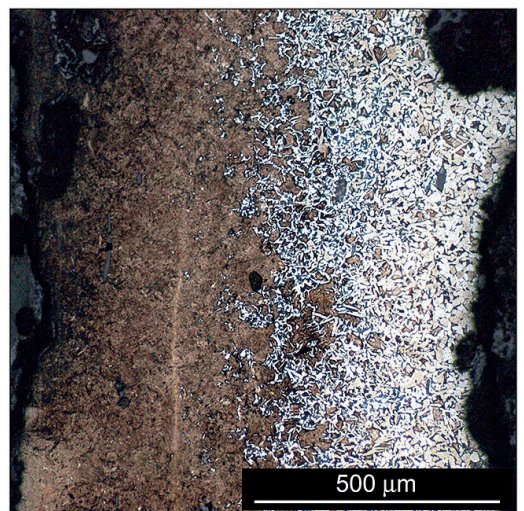

b

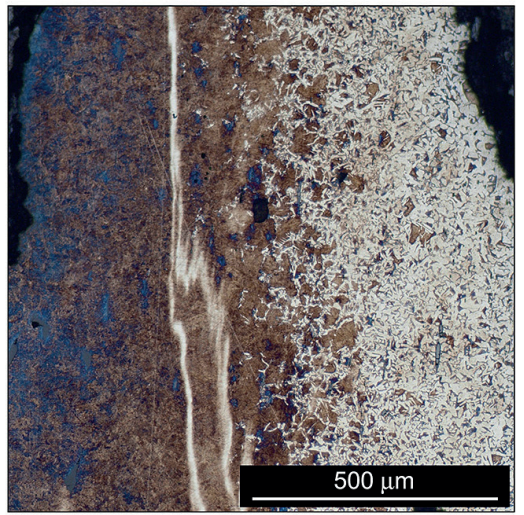

d

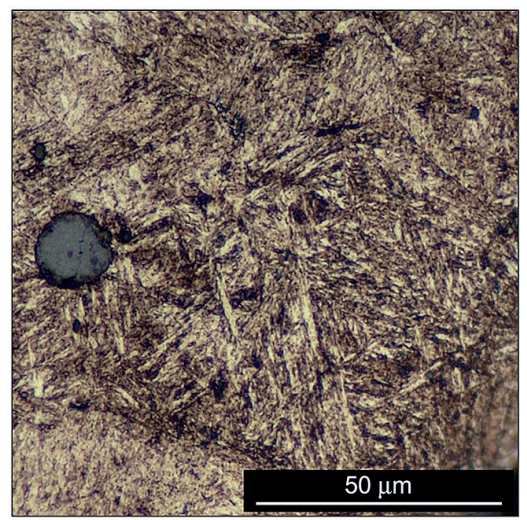

f

Obr. 7. Meč z Hoštic. a - popuštěný martenzit v oblasti I (břitu); b - makrofoto struktur v celé tloušt'ce vzorku A - nalevo oblast I, napravo oblast II, mírně napravo od středové osy oblast III; c - popuštěný martenzit prostoupený zrnky feritu v oblasti III - část nejblíže k břitu (vzorek A); d - prủběh svarové linie mezi jádrem a pláštěm čepele (vzorek A); e - průběh svarových linií v jádru, v blízkosti středu čepele (vzorek A); f - popuštěný martenzit v oblasti I.b (vzorek B); leptáno nitalem (a-c, f) a Oberhofferem (d, e).

Abb. 7. Schwert von Hoštice. a - angelassenes Martensit im Bereich I (Schneide); b - Makrofoto der Strukturen in der gesamten Dicke von Probe A - links Bereich I, rechts Bereich II, ein wenig rechts von der Mittelachse Bereich III; c - mit Ferritkörnern durchsetztes angelassenes Martensit im Bereich III - der am dichtesten an der Schneide befindliche Teil (Probe A); d-Schweißnahtverlauf zwischen Klingenkern und Klingenummantelung (Probe A); e - Schweißnahtverlauf im Kern, in der Nähe der Klingenmitte (Probe A); f - angelassenes Martensit im Bereich I.b (Probe B); Nitalätzung (a-c, f) und Oberhoffer Ätzung (d, e). 
V současné době máme $\mathrm{k}$ dispozici 32 mečů, jejichž datování zasahuje do 12. století a které byly metalograficky zkoumány. Odečteme-li případy, ve kterých nebylo možné stanovit konstrukci čepele s dostatečnou spolehlivostí, zbude nám devatenáct exemplářủ pocházejících především z Polska (8 ks) a České republiky (4 ks). Z nich třináct čepelí (včetně té na meči z Hoštic) má jádro zabalené v ocelovém plášti (Anteins 1964; Stankus 1970; Mapelli-Nicodemi-Riva 2007; Williams 2012, 254-255; Žákovský-Hošek-Sedláčková 2013; Košta a kol. 2014; ŻabińskiStępiński-Biborski 2014, 185-193, 197, 202-205, 211-217). To nasvědčuje tomu, že hoštický meč spadá do kategorie zbraní s nejběžnějším typem čepele té doby. Pouze čtyři další čepele ( $z$ toho dvě damaskované) měly břity navařené na středovou část. $V$ jednom dalším případě jde o neobvyklou čepel s jádrem zabaleným v ocelovém plášti, do které je v horní části zasazena vložka ze svářkového damasku (Selucká 2016, 35-38). Čepele opatřené damaskovými kompozity tak byly celkem tři (Biborski-Stępiński-Żabiński 2011, 89-90, 86-88; Selucká 2016, 35-38), ve všech př́ípadech však jde o čepele s konstrukcí nenavazující na damaskované meče 9. a 10. století, což svědčí o ztrátě původní tradice. Od 13. století jsou čepele mečů vyráběny bud'to z jednoho výchozího kusu oceli, nebo kombinují jádro s ocelovým přebalem. Zdá se, že přinejmenším do první poloviny 15 . století druhá varianta, kterou vidíme i na meči z Hoštic, dominovala.

Jestliže technologie používaná $\mathrm{k}$ výrobě čepelí v raném středověku byla vhodná pro ruční malovýrobu, tj. ruční kovářské svařování

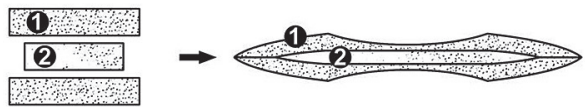

Obr. 8. Trojdílná konstrukce čepele s ocelovým pláštěm a železným jádrem.

Abb. 8. Dreiteilige Klingenkonstruktion mit Stahlummantelung und Eisenkern.
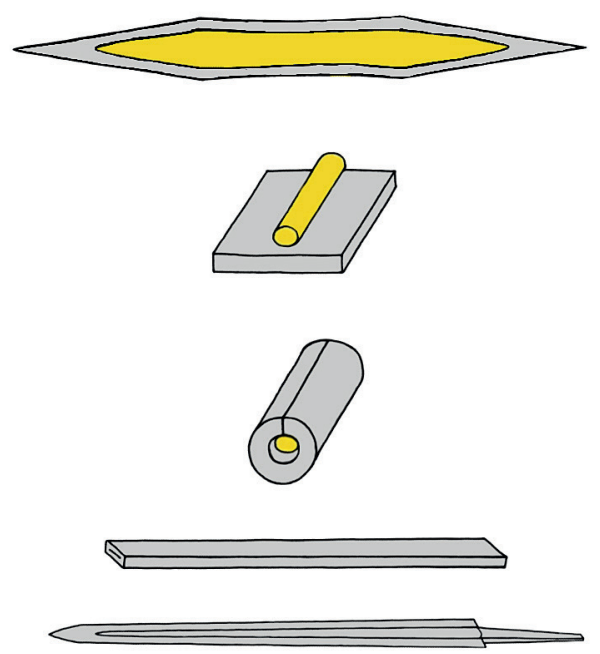

Obr. 9. Metalografickým průzkumem zjištěná konstrukce čepele (přičný řez: bílá ocel, žlutá železo) a rekonstruovaný postup její výroby.

Abb. 9. Durch metallographische Untersuchung festgestellte Klingenkonstruktion (Querschnitt: weiß - Stahl, gelb - Eisen) und rekonstruiertes Herstellungsverfahren der Klinge. z několika menších prutů, kde dva vždy tvořily ostř́i a jeden či více tvořil střed čepele (např. Hošek-Košta 2014, 284), naznačuje konstrukce meče $s$ ocelovým pláštěm a železným jádrem něco jiného. U výše zmíněné starší konstrukce čepelí může být závěrečné svařování čepele prováděno na několikrát (podle délky čepelí lze počet svařovacích ohřevů odhadnout na osm až deset), protože při úderech kladiva $\mathrm{v}$ rámci kovářského svařování má tavenina oxidů spolu $\mathrm{s}$ očištovacím prostředkem vždy prostor, kam odstříknout. Tato možnost je i u možné trojdílné konstrukce čepele $s$ ocelovým pláštěm a železným jádrem, kdy dvě desky tvoří plášt' a jedna tvoří jádro, přičemž v oblasti ostř́i jsou potom dva konstrukční svary (obr. 8). Tuto variantu ovšem považujeme za v praxi obtížně proveditelnou. Důvodem je vysoká expozice okrajů ocelových plátů $\mathrm{v}$ místě budoucího ostří při ohřevu na vysokou svařovací teplotu, kde je velmi snadné ocelový plát přehřát a tak znehodnotit. Ohřev je totiž komplikován tím, že železné jádro uvnitř nemá př́ímý kontakt s hořícím palivem ve výhni, a je proto velmi obtížné dosáhnout svařovací teploty i u něho. V př́ípadě dvojdílné konstrukce plášt' - jádro s jedním konstrukčním svarem na ostří (obr. 9) je tomu jinak. Svařovaný polotovar je kruhového profilu, tedy bez exponovaných hran, a ohřev na svařovací teplotu je $\mathrm{z}$ tohoto pohledu bezproblémový. Celková uzavřenost ocelové trubky pláště ovšem neumožňuje odchod výše 
zmíněné taveniny při parciálním svařování, z čehož plyne, že tato konstrukce čepele by musela být svařena najednou, či nadvakrát. Vzhledem k reálným možnostem ohřevu na vysokou svařovací teplotu a následnému svaření ohřátého místa kladivy si nelze představit délku svařence obdobnou, jako byla u raně stř̌edověkých čepelí. Ta musela být radikálně menší, aby bylo možno svar provést naráz, nebo maximálně nadvakrát. To ovšem předpokládá velmi masivní a krátký polotovar (průměr odhadem kolem $60 \mathrm{~mm}$, délka ca $120 \mathrm{~mm}$ ), který je prakticky neprokovatelný ručním kováním.

Nabízí se tudíž hypotéza, že dvojdílná konstrukce čepelí s ocelovým pláštěm a měkčím jádrem může být dokladem zavedení mechanizace (např. vodní hamr) do výroby mečových čepelí. Tuto tezi bude ovšem v budoucnu nutno potvrdit či vyvrátit dalším výzkumem. Tomu, že není úplně nereálná, napovídá ale i to, že čepele s měkčím jádrem a vnější ocelovou vrstvou byly vlastně známy už v raném středověku, ovšem vytvořeny podle tehdejší tradice $\mathrm{z}$ většího množství menších dílů, jak to dokládají například meče z hrobů 425, 438, 717 a 1750 z Mikulčic (Hošek-Košta 2014, 284). Přechod na dvojdílnou konstrukci kromě zjednodušení výroby tedy nemohl nic zásadně nového přinést. Pokud ovšem byla použita mechanizace, mohla dvojdílná konstrukce zpracovávaná na hamru znamenat radikální zrychlení výroby čepelí a tím i zvýšení jejich produkce a v konečném důsledku i dramatický pokles ceny mečů a nepochybně i částečnou devalvaci jejich symbolického významu, nebot' již nebyly dostupné pouze př́slušníkům tehdejších elit. Tato situace se však ve zvýšené míře projevila zejména až v průběhu 14. století.

\section{Iniciálová inskripce na čepeli}

Před konzervátorským zásahem byl meč nejdřive podroben rentgenografickému průzkumu, ${ }^{4}$ čímž se podařilo objevit zdobení čepele ve žlábku poblíž záštity, kde byly na snímku dobře viditelné litery latinské abecedy (obr. 10; Bárta-Hložek 2018). Rentgenový snímek naznačoval, že inskripce je pravděpodobně provedena z obou stran, jak o tom svědčí nepřesné překrytí znaků $O$ a $S$ a inverzní podoba jednoho z $S$. Tuto hypotézu potvrdil následný konzervátorský zásah, při kterém byl nápis z jedné strany odhalen. Druhá strana inskripce fyzicky odhalena nebyla vzhledem ke stavu předmětu a riziku př́lišného zeslabení čepele v daném místě. Druhá část nápisu tedy zůstala zdokumentována pouze zmíněným rentgenovým snímkem. Písmena inskripce jsou na snímku značně kontrastní vůči pozadí, což svědčilo pro inkrustaci nějakým neželezným kovem. Byl proto proveden rozbor prvkového složení mikrovzorku odebraného hrotem jehly Z odhalené části nápisu. ${ }^{5}$ Zkoumány byly celkem tři shluky vzorku (obr. 11; tab. 1). Analýza shluku 2 vykázala vyšší obsah cínu, který se pravděpodobně při procesu archeologizace předmětu přeměnil na své korozní produkty.
Tab. 1. Prvkové složení mikrovzorku odebraného z odhalené části nápisu (SEM-EDX; hm\%).

Tab. 1. Elementenzusammensetzung der vom freigelegten Teil der Inschrift genommenen Mikroprobe (SEM-EDX; hm\%).

\begin{tabular}{|c|c|c|c|}
\hline $\mathrm{Wt}[\%]$ & shluk 1 & shluk 2 & shluk 3 \\
\hline $\mathrm{Fe}$ & 87,36 & 40,43 & 65,63 \\
\hline $\mathrm{O}$ & 12,64 & 39,73 & 32,55 \\
\hline $\mathrm{Sn}$ & 0 & 19,36 & 0 \\
\hline $\mathrm{Ni}$ & 0 & 0,48 & 0 \\
\hline $\mathrm{Si}$ & 0 & 0 & 1,22 \\
\hline
\end{tabular}

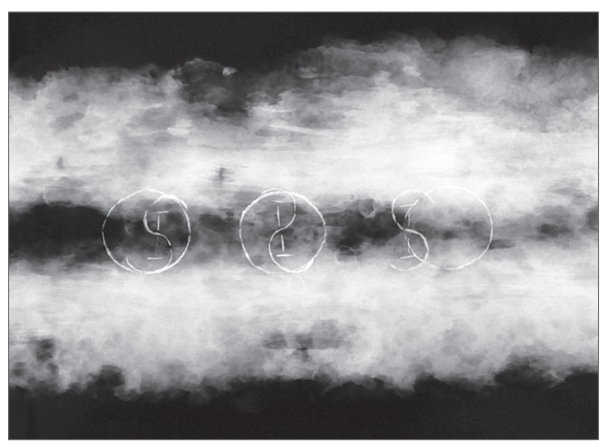

Obr. 10. Rentgenový snímek iniciálové inskripce na čepeli. Abb. 10. Röntgenaufnahme der Initialinschrift auf der Klinge.

4 Při snímkování byl použit př́stroj Blatnographe 200, přičemž technické podmínky snímkování byly: napětí 120 kV, proud $13 \mathrm{~mA}$, doba expozice $60 \mathrm{~s}$.

5 Prvkové složení bylo určeno za užití elektronového mikroskopu PHILIPS XL 30 s energiově disperzním analyzátorem (SEM-EDX). Byla užita bezstandardová analýza s dobou načitání spektra 100 s, urychlovací napětí bylo $20 \mathrm{kV}$. 


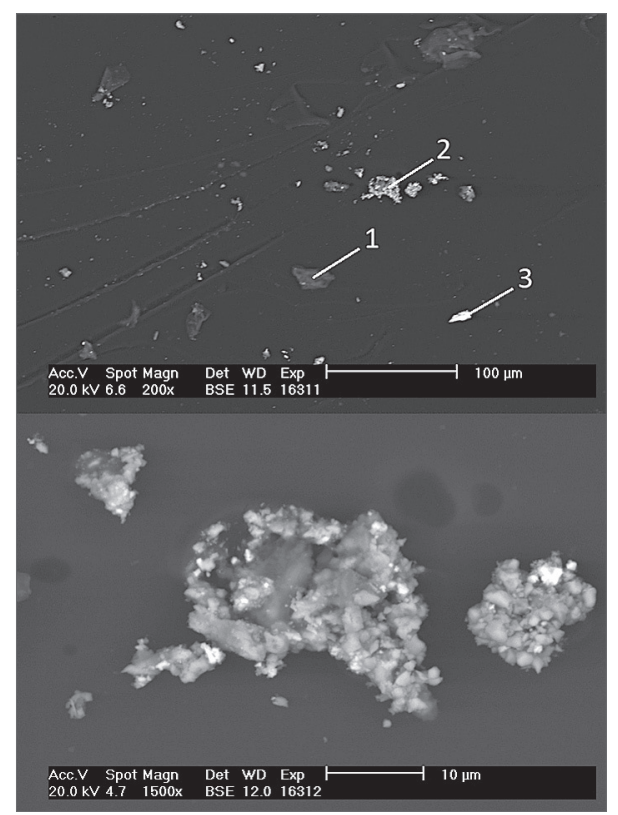

Obr. 11. Nahoře SEM snímek tř́i měřených shluků mikrovzorku M, dole snímek shluku 2 s obsahem cínu.

Abb. 11. Oben SEM-Aufnahme der drei gemessenen Ansammlungen der Mikroprobe M, unten Aufnahme von Ansammlung 2 mit Zinngehalt.
Odhalení inskripce přineslo ještě další důležité zjištění; linie jednotlivých liter nemají konstantní šírku (obr. 12). Nepochybně tedy mají profil ve tvaru písmene $\mathrm{V}$, kdy nerovnoměrným odběrem korozních produktů $\mathrm{v}$ rámci konzervátorského zásahu došlo $\mathrm{k}$ proměně šírky linky až k jejímu vymizení (obr. 13:a). Profil ve tvaru $\mathrm{V}$ ovšem vylučuje možnost, že by byly litery tauzovány. Pro aplikaci tauzie (inkrustace za studena) je totiž nezbytně nutný profil drážky ve tvaru písmene U s pravoúhlou základnou (obr. 13:b). Výrobní postup při vytvoření inskripce lze na základě výše zmíněných skutečností zrekonstruovat následovně. Nejdříve byly rydlem vyryty nebo rýhovákem vyraženy litery do povrchu žlábku meče. K vytvoření liter muselo dojít ještě před zakalením meče, protože po kalení by zvýšená tvrdost jejich provedení již neumožnila. Po zakalení byla celá čepel či jen místo inkrustace omořeno vhodným mořidlem a následně posypáno směsí cínových pilin a tavidla (např. kalafuna) a tato směs byla na povrchu čepele roztavena (teplota tání čistého cínu je $231,9^{\circ} \mathrm{C}$ ). Každá strana inskripce musela být provedena zvlášt'. Po dokončení byl přebytečný cín z místa inkrustace mechanicky odstraněn tak, že zůstal pouze ve výše zmíněných rýhách. Inskripce

neměla př́liš velký kontrast vůči matrici, nebot' rozdíl mezi barvou cínu a železa není velký. Na druhé straně se vzhledem k nízké teplotě tání inkrustační slitiny jednalo o jednoduchou metodu výzdoby, která nebyla při dekoraci mečových čepelí zcela neobvyklá (např. Ptáčková-Himmelová-Ustohal 1994). Teoreticky mohl být sekundární ohřev při inkrustaci použit zároveň i jako technologický krok nízkoteplotního popuštění čepele pro snížení její křehkosti.

Vlastní inskripce je sestavena z jednotlivých liter, přičemž na jedné ploše to je trojice písmen $S O S$, kdežto na druhé straně trojice liter $O S O$, přičemž litera $S$ je kombinována s písmenem $I$ do určité formy ligatury (obr. 3, 10).

Tímto typem inskripce se v minulosti zabývala celá řada autorů, přičemž lze shrnout, že se objevuje na poměrně nepočetné skupině mečů datovaných vesměs do průběhu 12. až první poloviny 14. století. Nejčastěji jsou jednotlivé litery za tepla inkrustované cínem, což zcela odpovídá i zjištění na hoštickém meči. S největší pravděpodobností lze odmítnout tvrzení některých autorů, kteří bez možnosti provedení analýz na jimi studovaných mečích tento bílý kov považovali za stř́ibro (např. Wegeli 1902-1905, 261; Post 1918-1920, 247; Oakeshott 1964, 142-143; 2002, 83; Głosek 1984, 147, kat. č. 132, 185).

Dané skupiny liter mohou být zapracovány do rozsáhlejších inskripcí, přináležejících například do skupiny nápisů DX. ${ }^{6}$ To je př́íklad torza dlouhého meče s čepelí Oakeshottova typu XIIIa z Eilenburgu u Lipska, který lze rámcově datovat do průběhu první poloviny 14. století. Na jedné ploše jeho čepele se objevuje skupina drobných liter $O S O$, která je dále kombinována s poměrně složitým ornamentem, jenž také rozděluje následnou inskripci EHRUSDXOEH a EHRUSDXOE.

6 Nepochybně se jedná o iniciálovou inskripci, kterou lze číst jako Dominus Christus (např. Post 1918-1920, 249).

7 M. Głosek navrhuje tuto velmi pravděpodobnou interpretaci: „Omnipotens Salvator Omnipotens - Eterne Honestus Rex Unicus Salvator Dominus (Jesus) Christus Omnipotens Eterne Honestus“" (Głosek 1984, 109). 

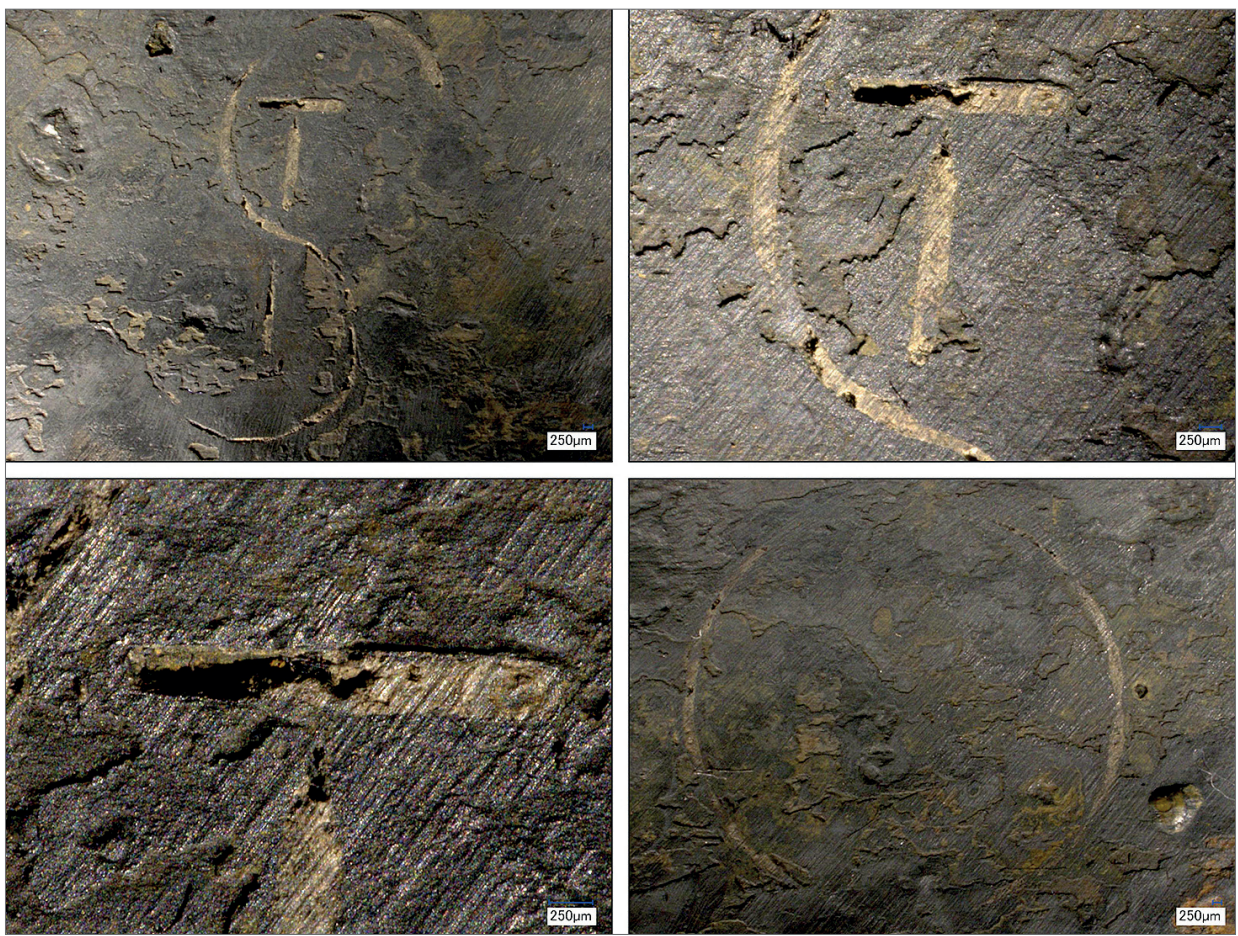

Obr. 12. Detaily ligatury SI s inkrustační výplní tvořenou degradovaným cínem a detail litery O s proměnlivou šířkou linky.

Abb. 12. Details der SI-Ligatur mit durch degradiertes Zinn gebildeter Inkrustierfüllung und Detail von Buchstabe $\mathbf{O}$ mit veränderlicher Linienbreite.

Na druhé ploše této čepele se pak nachází rozměrný a značně komplikovaný ornament, který je na jedné straně uzamčen opět drobnou skupinou liter $S O$, přičemž třetí $S$ lze dnes kvůli stavu dochování čepele pouze předpokládat (Głosek 1984, 109, 147, kat. č. 132, tab. VII; Chodyński-Żabiński 2011, 124).

Se složitější inskripcí, přináležející opět do skupiny nápisů DX se setkáváme rovněž na krátkém meči, který byl nalezen patrně někde na území dnešní Francie a který je dnes součástí sbírek Deutsches Historisches Museum v Berlíně. Jedná se o zajímavý krátký meč s čepelí Oakeshottova typu XII, záštity typu 1 a specifické hlavice typu M, který lze rámcově datovat do průběhu 13. století. Plochy této čepele jsou opět opatřeny poměrně složitým geometrickým ornamentem, ve kterém se uplatnilo i několik motivů kř́ižů. Kř́iž v kruhu ostatně rovněž vymezuje a i rozděluje iniciálovou inskripci ve znění: ?EHDXOEHRNUSDX

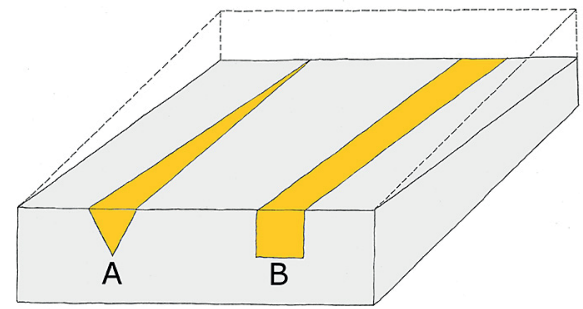

Obr. 13. Rozdíl v profilu rýh při inkrustaci za horka (A) a při tauzii, tj. inkrustaci za studena (B). Při odebrání povrchu předmětu obroušením či korozí dochází v případě A k zužování původní linky, v př́ípadě $B$ nikoli.

Abb. 13. Unterschied im Rillenprofil bei Inkrustierung unter Hitzeeinfluss (A) und bei Tauschierung, d.h. Inkrustierung bei Kälte (B). Bei Abnahme der Oberfläche eines Gegenstandes durch Schleifen bzw. Korrosion kommt es im Falle von A zu einer Verjüngung der ursprünglichen Linie, im Falle von B nicht. 
a ?EHDXOEHRNUSDX. ${ }^{8}$ Před touto inskripcí nalezneme skupinu o poznání menších liter OSO, která je od delšího nápisu oddělena opět geometrickým ornamentem. Na druhé ploše čepele se setkáme opět s geometrickým ornamentem a inskripcí NRISSDVT C+SBCNIS, ${ }^{9}$ přičemž před tímto nápisem se objevuje skupina liter SOS (Gay 1887, 641-642; Wegeli 1902-1905, 261-262; Post 1918-1920, 246-248, obr. 1:a, 2-3; Bruhn Hoffmeyer 1954, 10, kat. č. 41; Müller-Kölling 1984, 160, 166, 362, kat. č. 10; Głosek 1984, 109-110, 151, kat. č. 185; Oakeshott 2002, 83).

Čepel krátkého meče z průběhu 12. století Oakeshottova typu XII, A, 1, který byl vytažen z koryta řeky Peene u Wolkowa v Meklenbursku, je na jedné své ploše opatřena stylizovaným florálním motivem a na druhé straně pak iniciálovou inskripcí ve znění SOSMENRSOS,$^{10}$ přičemž v každé liteře $O$ je vepsáno písmeno $S$ a každá litera $S$, kromě těch vepsaných ve velkých písmenech $O$, je kombinována s dvěma malými literami $O$, které jsou vepsány v jejích ohybech (Wegeli 1902-1905, 223-224, obr. 18-19; Bruhn Hoffmeyer 1954, 10, kat. č. 42; Oakeshott 1960, 216-217, obr. 100; 1964, 142-143, obr. 132; Schoknecht 1969, 212; Müller-Kölling 1984, 158, 362, kat. č. 5; Głosek 1979, 66; 1984, 111, 151, kat. č. 174; Wagner 1993, tab. 15:1). Ve skutečnosti tak na daném meči nemáme pouze dva shluky liter $S O S$, ale napočítáme jich tak celkem osm. Např́iklad podle Řehoře Velikého symbolizuje číslo 8 věčný život, nebot' osmý den, totiž den po sabatu, měl Kristus vstát z mrtvých (např. Royt-Šedinová 1998, 21-22). Tato symbolika společně s předpokládaným zněním inskripce tak může vykazovat těsnou provázanost.

Skupinu liter $S O S$ nalezneme rovněž uprostřed delší inskripce na tzv. Szcerbci, přepychovém korunovačním meči polských králů. Zde však není nápis př́itomný na čepeli, ale na kovovém obložení rukojeti, přesněji na jeho boční stěně, a tudíž se studované skupině mečů výrazně vymyká. Proto se jím zde blíže zabývat nebudeme. Navíc tato zbraň byla v nedávné minulosti zevrubně publikována, včetně řady speciálních analýz (např. Żygulski 2008; Biborski-Stępiński-Żabiński 2009; 2011). Stačí zde jen zmínit, že celý text ve znění „CVM . QVO . EI DNS . OS . AVXIL . ETVR. ADUS . PARTES. AMEM“11 zajímavě koresponduje s textem ve Velkopolské kronice (Chronica Poloniae Maioris), kde je popisováno, jak Boleslav chrabrý dostal tento meč od anděla, aby se s jeho pomocí a s pomocí Boží chránil před svými nepřáteli (Głosek-Makiewicz 2007, 142; Biborski-Stępiński-Żabiński 2009, 246; 2011, 117-118).

Nejčastěji se však se studovanou kombinací liter v podobě $O S O$ a $S O S$ setkáváme samostatně, či v poněkud modifikované podobě, kdy je litera $S$ vepsána do písmene $O$ (např. Oakeshott 1964, 142-143; Geibig 1991, 130-132). Tímto typem iniciálové inskripce je opatřena celá řada mečů z průběhu 12.-14. století, přičemž se mohou jednotlivé skupiny liter na mečích objevovat samostatně nebo v kombinaci tak, že na jedné ploše čepele je situována inskripce $S O S$, kdežto na druhé ploše pak skupina liter $O S O$ (např. Geibig 1991, 157).

Samostatnou iniciálovou inskripci ve znění $S O S$ máme evidovánu např́klad z krátkého, blíže nelokalizovaného meče Oakeshottova typu XI, B, 3 ze sbírek Muzeum Wojska Polskiego ve Varšavě, který lze rámcově datovat do přelomu 12. a 13. století (Głosek 1973, 159, kat. č. 79, tab. IX:1; 1984, 111, 169, kat. č. 396). Do průběhu 12. století je rovněž datováno torzo blíže nelokalizovaného meče Oakeshottova typu XII, A, 3 ze sbírek Magyar Nemzeti Múzeum v Budapešti, kde se objevuje kombinace obou iniciálových inskripcí, přičemž jednotlivé litery jsou vyplněny bílým kovem (např. Głosek 1984, 112, 174, kat. č. 458; Aleksić 2007, 36, 121, 153, kat. č. 96). Obdobně lze datovat rovněž krátký meč Oakeshottova typu XIa, E, 1 ze sbírek Royal Armouries v Leedsu, který nese pouze na jedné ploše své čepele iniciálovou inskripci ve znění SOS (Dufty 1974, 14,

\footnotetext{
8 M. Głosek navrhuje tuto velmi pravděpodobnou interpretaci: „Omnipotens Salvator Omnipotens - Eterne Honestus Dominus (Jesus) Christus Omnipotens, Eterne Honestus Rex Noster Unitor Salvator Dominus (Jesus) Christus, Eterne Honestus Rex Noster Unitor Salvator Dominus (Jesus) Christus" (Głosek 1984, 110).

9 Danou inskripci se dodnes nepodařilo rozluštit, nehledě na fakt, že v literatuře se samotné čtení značně liší, což s ohledem na ornamentálnost použitých liter není nijak překvapující. Ve studii P. Posta se setkáme se čtením NRISSDVIX+SBENIS (Post 1918-1920, 247) a v díle H. Müllera a H. Köllinga pak s interpretací jako +NRISSDIADG+SBENIS+. Tito autoři pak nabídli i poněkud rozdílnou interpretaci nápisu na druhé ploše čepele jako MEHDXOEHRNISDX + MEHDXOEHRNISDX+, přičemž zcela pomíjejí soubor liter SOS a OSO (Müller-Kölling 1984, 362).

10 Inskripci lze číst „Salvator Omnipotens Salvator Magnificus Eterne Noster Rex Salvator Omnipotens Salvator“ (Głosek 1984, 112).

11 Nápis lze číst „Cum quo ei Dominus omnium salvator auxilietur adversus partes amen“ (Biborski-Stępiński-Żabiński 2011, 117-118).
} 
tab. 2:c; Oakeshott 2002, 63). Do průběhu 12. století lze nejspíše datovat i čepel Oakeshottova typu X z jedné soukromé sbírky, která je opatřena druhotně vyrobenou garniturou rukojeti. Čepel nese po obou svých plochách shodnou inskripci ve znění $O S O$ (Oakeshott 2002,33). Skupinu liter OSO nalezneme rovněž na jedné ploše čepele blíže nelokalizovaného krátkého meče Oakeshottova typu XII, E, 2 ze sbírek Royal Scottish Museum v Edinburgu, který lze rámcově datovat zhruba do poloviny 13. století (Oakeshott 2002, 97). Obdobně je datován rovněž krátký meč Oakeshottova typu Xa, B, 1 nalezený počátkem 20. století na hradišti v Rodingu, který je na jedné ploše opatřen skupinou liter $O S O$ a na druhé pak $S_{S} S^{12}$ (Wegeli 1902-1905, 224, obr. 19-20; Bruhn Hoffmeyer 1954, 11, kat. č. 49; Schmid 1918-1920, 246, obr. 6; Schoknecht 1969, 217; Głosek 1984, 112; Geibig 1991, kat. č. 42, tab. 31; Aleksić 2007, 36, 121; Chodyński-Żabiński 2011, 124).

Do přelomu 13. a 14. století je pak obecně datován meč ze sbírek leningradské Ermitáže, který měl být údajně nalezen na blíže neznámém místě v Rusku. Čepel této zbraně nese na jedné straně inskripci $S O S$ a na druhé pak $O S O$. Z tvarů písmen $S$ se zdá, že jsou vytvořena dvěma protilehlými údery obloukovitě profilovaného rýhováku (Wegeli 1902-1905, 223-224; Ленцъ 1908, 302, kat. č. 581; tab. XXIX:3; Кирпичников 1966, 56, tab. XXIX:3; Głosek 1973, 65; 1984, 112; Aleksić 2007, 36, 121). Pouze rámcově do průběhu 14. století je datován i meč z lotyšské lokality Pasiles (Пассельн), který je po obou plochách čepele opatřen inskripcí OSO (Кирпичников 1966, 56, obr. XXIX:4; Głosek 1984, 112; Chodyński-Żabiński 2011, 124). U obou zbraní pocházejících z území Ruska však musíme brát navrhovanou dataci pouze orientačně, nebot' díky nedostupnosti kvalitnější dokumentace ji nelze blíže verifikovat. Ve stejné pozici jsme i při případném posuzování údajného meče s torzem inskripce, ze které se zachovaly pouze litery $S O$, ze sbírek Germanisches Nationalmuseum v Norimberku (Wegeli 1902-1905, 223-224, obr. 20), i u blíže neznámého meče s inskripcí SOS pocházejícího údajně z Hamburku (Geibig 1991, 130). Do první poloviny 14. století lze rámcově datovat i blíže nelokalizovaný meč ze sbírek Nationalmuseet v Kodani, který na jedné ploše čepele nese inskripci ve znění OSO (Wegeli 1902-1905, 224; Bruhn Hoffmeyer 1954, 15, kat. č. 9, tab. XV:a). Stejnou inskripci nalezneme i na torzu meče z průběhu první poloviny 14. století, které mělo být nalezeno v Kleinhünigenu (Bruhn Hoffmeyer 1954, 9, kat. č. 20a).

Iniciálové inskripce studované skupiny se objevují, byt' prozatím zcela ojediněle, ještě na čepelích dlouhých mečů z průběhu druhé poloviny 14 . století. Tak lze alespoň bezpečně datovat blíže nelokalizovaný meč Oakeshottova typu XIIa, I, 7 ze Štětína, který na obou stranách čepele nese skupinu liter OSO (Chodyński-Żabiński 2011, 124-126, obr. 14-15).

$\mathrm{S}$ danou skupinou nápisů podle našeho názoru úzce souvisí také poměrně značně rozšriřený typ inskripce, který by snad v některých případech mohl plnit i funkci výrobní mečířské značky (např. Głosek 1973, 132; 1984, 60). ${ }^{13}$ Představuje jej majuskulní litera $S$, která je vepsána do kruhu. Tento kruh však lze nejspíše důvodně interpretovat jako písmeno $O$, které tak s předešlou literou vytváří určitý druh ligatury. S největší pravděpodobností lze tuto kombinaci číst jako Salvator Omnipotens. S uvedenou kombinací liter se setkáváme již na mečích z průběhu 12. století, ze kterých lze uvést např́klad meč Oakeshottova typu XI, G, 1 z Rübelandu, kde je písmeno $S$ situováno dokonce ve dvou kruzích, či spíše oválech, takže bychom jej mohli číst jako OSO. Tato inskripce je na ploše čepele kombinována s dvěma drobnými řeckými křǐžky ve zdvojeném kruhu, přičemž tyto motivy od sebe odděluje stylizovaný florální motiv. Na druhé ploše čepele se setkáváme s charakteristickými třemi skupinami tří vertikálních linií, které lze interpretovat jako trichotomii litery I, interpretovatelnou jako iniciálu jména Jesus (Schröter 1969; Głosek 1984, 138, kat. č. 162). Tato eventualita se s ohledem na kombinaci liter $S O$ na druhé ploše čepele zdá jako velmi pravděpodobná. Do průběhu 12. století lze rovněž datovat blíže nelokalizovaný meč Oakeshottova typu XI, E, 3 ze sbírek Zámeckého muzea v Malborku, na němž je studovaná kombinace

12 Garnitura rukojeti tohoto meče je klasifikována jako kombinační typ 15-IV (15-22-11-14) a čepel jako typ 8 (Geibig 1991, kat. č. 42).

13 Tento fakt potvrzuje i skutečnost, že se litera $S$ objevuje, byt' poměrně ojediněle, také jako signatura na řapech středověkých mečů, a je obecně považována za výrobní či technologickou značku. Literou S je značen například dlouhý meč, který ve svých sbírkách chová Muzeum Narodowe ve Vratislavi (napr. Głosek 1973, 158, kat. č. 75) či Muzeum Wojska Polskiego ve Varšavě (např. Głosek 1973, 159-160, kat. č. 80). 

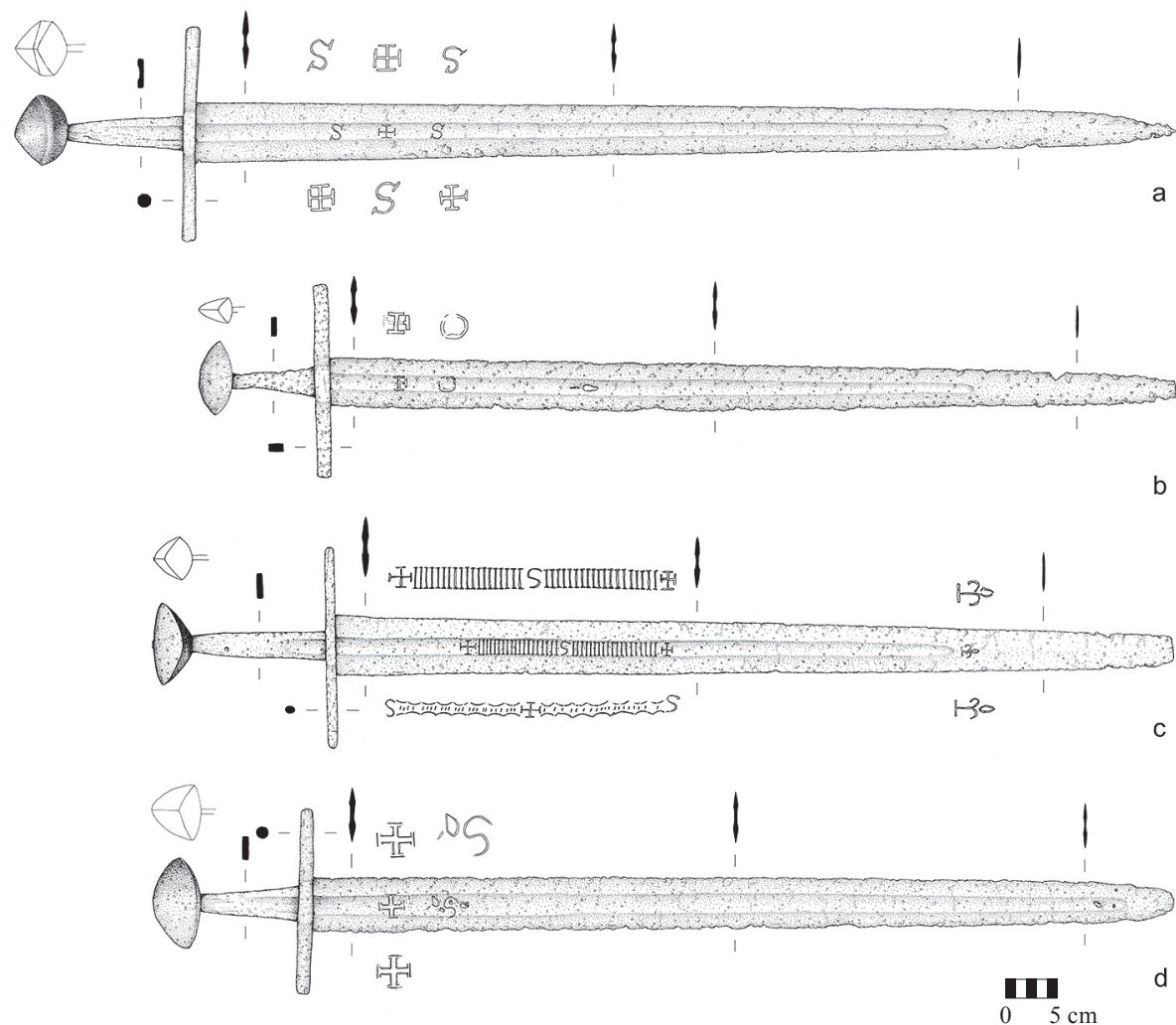

Obr. 14. Vybrané románské meče s literami I, S a O na čepeli: a - Šintava, Mestské múzeum Sered', bez inv. č.; b - nelokalizovaný románský meč ze sbírek Muzea Mladoboleslavska v Mladé Boleslavi (podle Hošek-Košta-Žákovský 2019, kat. č. 334); c - nelokalizovaný románský meč ze sbírek Státního zámku Žleby (podle Hošek-Košta-Žákovský 2019, kat. č. 428); d-nelokalizovaný románský meč ze sbírek Masarykova muzea v Hodoníně (podle Hošek-Košta-Žákovský 2019, kat. č. 299).

Abb. 14. Ausgewählte romanische Schwerter mit den Buchstaben I, S und $O$ auf der Klinge: a - Šintava, Stadtmuseum Sered, ohne Inv-Nr.: b - nicht lokalisiertes romanisches Schwert aus den Sammlungen des Museums der Region Mladá Boleslav in Mladá Boleslav (nach Hošek-Košta-Žákovský 2019, Kat. Nr. 334); c - nicht lokalisiertes romanisches Schwert aus den Sammlungen des Staatlichen Schlosses Žleby (nach Hošek-Košta-Žákovský 2019, Kat. Nr. 428); d - nicht lokalisiertes romanisches Schwert aus den Sammlungen des Masaryk-Museums in Hodonín (nach Hošek-Košta-Žákovský 2019, Kat. Nr. 299).

liter doprovázena na druhé ploše čepele jednoduchým berličkovým křížkem (Głosek 1984, 57, 166, kat. č. 362). Obdobně je datováno rovněž torzo blíže nelokalizovaného meče Oakeshottova typu XI, -, 1 ze sbírek Magyar Nemzeti Múzeum v Budapešti, jehož čepel je po obou plochách opatřena danou ligaturou $S O$ (Głosek 1984, 174, kat. č. 456; Aleksić 2007, 153, kat. č. 94).

Ve větší míře se pak s takto koncipovanou kombinací liter setkáváme na mečích obecně datovaných do průběhu 13. století. Na jedné ploše čepele meče Oakeshottova typu XI, D, 1 z Husinné je situována iniciálová inskripce ve znění MVSEMDNVS a na druhé ploše pak dvě studované sdružené litery $S O$, které jsou od sebe odděleny signaturou v podobě kotvicového křŕže v kruhu (Ruttkay 1971, 164-167, tab. IV; 1975, 145, kat. č. 57, obr. 13:3; 1976, 283; 1978, 105, obr. 26; Głosek 1984, 117, 138, kat. č. 9). Na torzu meče Oakeshottova typu XII, I, - z Poznaně je kombinace liter $S O$ poněkud netradičně spojena se stylizovanou lilií. Na druhé ploše čepele je pak situována signatura $\mathrm{v}$ podobě berličkového kř́iže v kruhu kombinovaného s větším berličkovým křížem, který je se zmíněným kruhem spojen krátkou linií (Głosek 1973, 146, kat. č. 32; 1984, 161, 
kat. č. 296). Torzo studovaného typu ligatury nalezneme rovněž na zbytku meče Oakeshottova typu -, B, 1 z jezera Bielersee u Bernu (Wegeli 1902-1905, 223-224; Bruhn Hoffmeyer 1954, 10, kat. č. 27; Głosek 1973, 66; Schneider-Stüber 1980, 25, kat. č. 20).

Daný typ ligatury $S O$ se však objevuje nejčastěji až na dlouhých mečích z průběhu 14. století. Mohli bychom konstatovat, že tato redukovaná forma postupně nahrazovala původní iniciálové inskripce $S O S$, respektive $O S O$, které v tomto časovém úseku pomalu z čepelí mečů mizí. Do přelomu 13. a 14. století lze celkem spolehlivě datovat dlouhý meč Oakeshottova typu XIIIa, I1, 1 z Nysy, jehož jedna plocha čepele je signována maltézským křížem v kruhu a druhá plocha pak ligaturou $S O$ (Głosek 1973, 113, 143, kat. č. 23, tab. XV:2; 1984, 160, kat. č. 280). Obdobně je signován i blíže nelokalizovaný dlouhý meč Oakeshottova typu XIIIa, I1, $1 \mathrm{~b}$ ze sbírek Muzea v Łowiczu (Głosek 1984, 166, kat. č. 358). Obě zmíněné zbraně by snad s ohledem na jejich shodný charakter i analogické signování mohly pocházet z jedné mečířské dílny.

Ve větší míře se ligatury daného typu objevují na specifickém typu dlouhých mečů, jež jsou charakteristické především pro průběh první poloviny 14. století a které lze klasifikovat Oakeshottovým typem XIIIa, K, 1, respektive XIIIa, K, 2. To je případ dlouhého meče, který byl vytažen z koryta řeky Tina u obce Raczki Elbląskie, kde je ligatura $S O$ na druhé ploše čepele doprovázena signaturou v podobě berličkového kř́žze v kruhu (Marek 2014, 57, tab. 21). Na dlouhém meči z polské Jelení Hory se na jedné ploše jeho čepele nachází ligatura $S O$ v doprovodu dvou maltézských kř́źžů v kruhu, kdežto na druhé ploše čepele je tato kombinace poněkud modifikována. Objevuje se zde totiž dvojice ligatur $S O$ rozdělená jedním maltézským křížem v kruhu (Marek 2008, 72, tab. 88). Na překrásném dlouhém meči Oakeshottova typu XIIIa, J, 2, vyloveném z koryta Visly u Gniewu je výzdobný a symbolický program jeho čepele značně komplikovanější. Na jedné ploše se objevuje litera $S$ vepsaná do zdvojeného kruhu, což opět nabízí interpretaci stylizované iniciálové inskripce $O S O$, kterou dále doplňuje dvojice drobných maltézských křižǩ̊ a rovněž rozměrná signatura v podobě krŕ́žkového křŕže v kruhu, která je následována drobnými literami $A$ a $R$. Celou kompozici pak završuje rozměrný tlapatý kř́ž ve zdvojeném kruhu. Na druhé ploše čepele je tento výzdobný program mírně modifikován. Na prvním místě, respektive nejblíže $\mathrm{k}$ záštitě se objevuje rozměrná signatura $\mathrm{v}$ podobě tlapatého křiže $\mathrm{v}$ kruhu, následována dvojicí drobných maltézských kř́ǐzoủ, rozměrnou šesticípou rozetou v kruhu a dvojicí drobných liter $A$ a $R$. Celá kompozice je završena rozměrnou literou $S$ vepsanou do zdvojeného kruhu (Żabiński 2017, 164-165, obr. 5).

Ligatura $S O$, respektive litera $S$ vepsaná do kruhu, se objevuje i na dlouhých mečích opatřených čepelemi s výraznými hroty, které lze rámcově datovat do průběhu 14. až počátku 15. století. Do této kategorie lze přiřadit dlouhý meč Oakeshottova typu XVIa, K, 5 z Kalné nad Hronom, jehož čepel je na jedné ploše opatřena signaturou v podobě drobného srdce, následovanou iniciálovou inskripcí v předpokládaném znění $V D G N$, která je uzamčena rozměrnou signaturou v podobě maltézského kříže v kruhu. Na druhé ploše čepele je výzdobný program uspořádán z drobného rovnoramenného křriže následovaného inskripcí v předpokládaném čtení RHAP a zakončeného literou $S$ v kruhu (Ruttkay 1975, 148, obr. 13:4; 1976, 283-284, obr. 27:2, 29:6; Głosek 1984, 117, 138, kat. č. 11). Na blíže nelokalizovaném dlouhém meči Oakeshottova typu XVIa, I1, 1 ze sbírek Šarišského muzea v Bardejově je ligatura $S O$ na druhé ploše čepele doprovázena rozměrnou signaturou v podobě tlapatého kř́iže v kruhu a dvojicí drobných, blíže neidentifikovatelných značek pod záštitou (Głosek 1984, 140, kat. č. 34). Obdobně je značen i blíže nelokalizovaný meč ze slavné sbírky kořistných evropských mečů, uložených dnes v Topkapi Museum v Istanbulu. Zde je tato ligatura doprovázena na druhé ploše čepele berličkovým křížem v kruhu (Alexander 1985, 86, 92, kat. č. 40). Do přelomu 14. a 15. století lze rovněž datovat torzo dlouhého meče Oakeshottova typu XVII, T2, -, který je chován ve sbírkách Muzeum Archeologiczne Środkowego Nadodrza w Zielonej Górze, jehož čepel je taktéž opatřena studovaným typem ligatury (Michalak 2007, 221-222, obr. 8; 2019, 89-90, tab. 38:8-9).

Poněkud složitější je případná interpretace samostatných liter $S$, které nejsou součástí delších inskripcí a nejsou ani kombinovány s literou $O$ či $I$. V daném případě je totiž lze považovat 
jak za iniciálu slova Sanctus (např. Głosek 1984, 60; Żabiński 2017, 169, 175), tak slova Salvator, které se ve středověké epigrafice spojuje takřka výhradně s Kristem (např. Głosek 1984, 112). Samostatné litery $S$ se však v doposud evidovaném materiálu objevují jen sporadicky. Máme je doloženy již na mečích z průběhu 11. až 13. století. Tak lze datovat např́íklad torzo meče Oakeshottova typu Xa, B, 1 z Vojlovici, kde je na jedné ploše čepele situována rozměrná litera $S$ (Aleksić 2007, 121, 165, kat. č. 228, obr. 6). Obdobně je značena i čepel meče Oakeshottova typu Xa, F, 2 z přelomu 12. a 13. toletí z koryta řeky Ljubljanica (Alesić 2007, 181, kat. č. 383). Do 13. století lze rámcově datovat blíže nelokalizovaný meč Oakeshottova typu XII, A1, 1 ze sbírek Magyar Nemzeti Múzeum v Budapešti, který je na jedné z ploch čepele opatřen dvojicí liter $S$ rozdělenou rovnoramenným křížem (Głosek 1984, 57, 174, kat. č. 460), i meč Oakeshottova typu XII, B, 2 ze sbírek Mestského múzea v Seredi, který údajně pochází z areálu hradu Šintava, respektive z koryta řeky Váh. Tato zbraň je na jedné ploše hrubí opatřena literou $S$, kterou z obou stran ohraničují značky v podobě berličkových křížů, kdežto na druhé straně čepele se setkáme s dvojicí liter $S$ vzájemně oddělených berličkovým křížem (obr. 14:a; Labuda 2016, 65-68).

Ojediněle se objevují i na mladších mečích z průběhu 14. století. Tak lze rámcově datovat blíže nelokalizovaný dlouhý meč Oakeshottova typu XVIa, -, la ze sbírek poznaňského muzea (Wielkopolskie Muzeum Wojskowe), který je po obou plochách své čepele vybaven velkou literou $S$, kombinovanou s dnes blíže neurčitelnými dalšími symboly (Głosek 1973, 97, 162, kat. č. 90, tab. XXXVIII:2; 1984, 167, kat. č. 373).

Není jistě bez zajímavosti, že ani jeden z výše uvedených mečů není signován značkou v podobě běžícího zvířete, tedy tzv. pasovského vlka, či signaturou v podobě biskupské berly, které lze obecně spojit s výrobním střediskem v bavorském Pasově. V tomto ohledu jedinou výjimku představuje meč Oakeshottova typu XIIIa, K, 1 z koryta řeky Dunaje, na němž je litera $S$ doprovázena právě značkou v podobě běžícího zvířete (Głosek 1984, 62, 172, kat. č. 430). Jistou výjimku by mohl v tomto ohledu představovat i již výše zmíněný luxusní meč z Kalné nad Hronom, kde se těsně pod záštitou setkáváme s drobnými značkami v podobě srdce a rovnoramenného kříže. Tyto drobné signatury, které mohou představovat individuální značky výrobce čepele, se totiž takřka výhradně objevují na charakteristickém typu dlouhých mečů signovaných kombinací značek v podobě tzv. pasovského vlka a jednorožce (srov. Hošek-Košta-Žákovský 2020). Lze tedy konstatovat, že meče opatřené literami $S$ nelze nejspíše s tímto věhlasným bavorským výrobním centrem spojovat. Patrně se jedná o produkty jiných, za dnešního stavu poznání jen těžko blíže lokalizovatelných mečiřských dílen v západní či stř̌ední Evropě. V této souvislosti není bez zajímavosti, že se samostatné litery $S$, stejně jako iniciálové inskripce $S O S$ či $O S O$, takřka neobjevují v jihovýchodní části starého kontinentu. Lze také konstatovat jistou vazbu liter $S$ či studovaných ligatur na signatury v podobě různých forem kř́ižů (např. Głosek 1984, 55, 60). Ty nám však v př́ípadné lokalizaci produkčních center takto značených a zdobených čepelí nemohou napomoci, nebot' se jedná o nejrozšířenější symbol, se kterým se na mečích setkáváme po celý středověk.

Tyto závěry jednoznačně podporuje i materiál evidovaný prozatím z území České republiky. Odtud máme podchyceny prozatím pouhé čtyřri exempláře mečů, které jsou signovány literou $S$ v kruhu, respektive ligaturou $S O$. Nejstarší z nich představuje blíže nelokalizovaný meč Oakeshottova typu XII, D, 1 z přelomu 12. a 13. století, který je součástí proslulé zbrojnice Státního zámku Hluboká nad Vltavou. Na jedné ploše je čepel této zbraně opatřena literou $S$ v kruhu a druhá strana nese berličkový kř́íž v kruhu (Pertl 1992, 403-404, obr. 5-7; Vaverková 1992, obr. 2; Hošek-Košta-Žákovský 2019, 295-296, kat. č. 297). Ostatní zbraně z českých sbírek lze přiřadit $\mathrm{k}$ výše zmíněné skupině specifických dlouhých mečů z průběhu 14. století. Na dlouhém meči Oakeshottova typu XVIa, K1, 2, údajně pocházejícím z Chotěboře, je po obou plochách jeho čepele situována poměrně rozměrná ligatura $S O$ (Pertl 1991, 194, obr. 1-2; Hošek-Košta-Žákovský 2019, 92, kat. č. 39). Krásně dochovaný dlouhý meč Oakeshottova typu XIIIa, J, 2 z hradu Helfenburka nese na jedné ploše své čepele literu $S$ ve zdvojeném kruhu a na druhé signaturu v podobě tlapatého kříže ve zdvojeném kruhu (Pertl 1992, 403-404, obr. 1-3; Vaverková 1992, 
obr. 2; Hošek-Košta-Žákovský 2019, 104-105, kat. č. 56). Přepychový dlouhý meč Oakeshottova typu XIIIa, K, 2 z Kolína má na jedné ploše čepele situovánu čtveřici maltézských křížů v kruhu a na druhé ploše pak čtveřici liter $S$ v kruhu (Głosek 1984, 143, kat. č. 76; Kočí-Vondruška 1989, 92, kat. č. 282; Šnajdrová 2014, 14, obr. 7; Hošek-Košta-Žákovský 2019, 121-122, kat. č. 78).

Litery $O$ se oproti písmenu $S$ objevují na středověkých mečích převážně zakomponované do delších a komplikovanějších inskripcí. V samostatném postavení se objevují pouze ojediněle, přičemž v řadě př́padů nejsme schopni rozhodnout, zda se skutečně jedná o literu, či o prostý kruh ohraničující nějaký jiný výzdobný motiv. V tomto postavení se jejich výskyt váže v převážné většině na románské meče z průběhu 11.-13. století (napřr. Głosek 1984, kat. č. 53, 137, 278; Geibig 1991, kat. č. 35, 36, 47, 64, 176, tab. 26, 27, 46, 110; Rageth 2000). V menší míře se pak objevují na dlouhých mečích z průběhu 14. století (Głosek 1984, kat. č. 173, 216, 414).

Tomuto zjištění neodporují ani dosud evidované nálezy mečů se solitérní literou $O$ na čepeli z území České republiky. Na jedné ploše čepele je jí opatřen meč z přelomu 11. a 12. století Oakeshottova typu X, A, 1 ze sbírek mladoboleslavského muzea (Hošek-Košta-Žákovský 2019, kat. č. 334). V tomto př́ípadě je litera doprovázena symbolem v podobě berličkového kříže (obr. 14:b). Do průběhu 12. až počátku 13. století lze datovat i blíže nelokalizovaný meč Oakeshottova typu XI, B, 1 ze sbírek Národního muzea v Praze, který nese na ploše čepele pouze literu $O$ (Hošek-Košta-Žákovský 2019, kat. č. 382).

V některých př́padech se písmeno $O$ druží s písmenem $I$, což je opět charakteristické především pro meče z průběhu 12.-13. století (např. Głosek 1984, kat. č. 35). V nálezovém fondu z území dnešní České republiky je takovou kombinací opatřen blíže nelokalizovaný meč Oakeshottova typu XII, B, 1 z přelomu 12. a 13. století ze sbírek Národního muzea v Praze (Wagner 1959, 125, obr. 2; 1993, 106, tab. 13:1; Kočí-Vondruška 1989, 63, kat. č. 189; Šnajdrová 2014, 12, obr. 2; Hošek-Košta-Žákovský 2019, kat. č. 63). Na jedné ploše je hrubí čepele opatřeno v pravidelných rozestupech třemi literami $O$ a na druhé ploše pak třemi skupinami tř́i vertikálních linií, které lze interpretovat jako třikrát opakované písmeno $I$. Tato trichotomie litery $I$, představující nepochybně třikrát opakované Spasitelovo jméno, je opět velmi typická pro románské meče, na nichž se v různých variantách objevuje především v průběhu 11.-12. století (Demo 1984, 218-225, tab. 1:2; Głosek 1984, kat. č. 162, 337, 407, 440; Geibig 1991, kat. č. 28, 38, 43, 49, 52, 56, 78, 86, 91, 181, 235, 237, 249; Kurasiński-Pudło 2009, 297-298; Hošek-Košta-Žákovský 2019, kat. č. 394). V ideovém programu této výzdoby nepochybně navazují zmíněné románské meče na své starší předchůdce, zejména na zbraně s čepelemi opatřenými nápisy ULFBERHT a INGELRII, u nichž se setkáváme na opačné ploše jejich čepelí s podobnými strukturami, které lze interpretovat jako opakující se písmeno $I$ doprovázené geometrickým, mřížovému rastru podobným dekorem, který lze interpretovat jako opakující se literu $X$ (srov. Forrer 1918-1920, 255-256; Malinowski 1975; Geibig 1991, 116-126; Peirce 2002, 95, 100-101; Kurasiński-Pudło 2009). Domníváme, že by se tudíž mohlo jednat o stylizovanou iniciálovou inskripci Jesus Christus.

S kombinací liter $I$ a $O$ se setkáváme ještě na dlouhých mečích z průběhu 14 . století, byt' zcela sporadicky. Za př́íklad lze uvést blíže nelokalizovanou zbraň Oakeshottova typu XIIIa, H, la ze sbírek Muzeum w Jaworze. Tato zbraň je na jedné ploše opatřena iniciálovou inskripcí ve znění $O I O$ a na druhé ploše pak IOI, což lze nepochybně číst jako Omnipotens Jesus Omnipotens, respektive Jesus Omnipotens Jesus, přičemž inskripce je doprovázena signaturou v podobě tzv. pasovského vlka (Głosek 1973, 67, 151, kat. č. 50, tab. XVII:1).

Jinak se litery $I$ objevují většinou jako součásti rozsáhlejších inskripcí a v solitérní poloze se s nimi na čepelích setkáváme jen v jednotlivých př́ípadech (např. Дрбоглав 1984, 46). Sérii těchto liter různě pootočených vůči ose čepele, vytvářejících tak iniciálovou inskripci $I H$ nalezneme např́íklad na meči z průběhu 11. až počátku 13. století z Píseckých hor (Košta a kol. 2014, 305-306). V delších inskripcích je písmeno $I$ velmi často svázáno s literami $N$ a $S$, což opět může tvořit zkratku Salvator Jesus. Často se tato kombinace liter vyskytuje u nápisů, které lze považovat do určité míry za palindrom (např. Ullmann 1958; Malinowski 1975, 117-118). Například na meči datovaném do průběhu 12. století ze sbírek Kunstsammlungen der Veste Coburg 
se objevuje iniciálová inskripce ve znění SININIS (Geibig 1990; 1996, 64-65; Scalini 2007, 104-105). Př́ípadné oboustranné čtení nápisu nelze zcela vyloučit ani u meče Oakeshottova typu XI, A, 1 z průběhu 11. a 12. století ze sbírek Franjevačka gimnazija ve Visoko, který je opatřen nápisem SIETRVS (Sijarić 2014, 58-61). Nelze to vyloučit ani u luxusního meče z průběhu druhé poloviny 10. až 11. století, pocházejícího z koryta řeky Sava pod lokalitou Bosanska Gradiška, jenž nese na čepeli iniciálovou inskripci ve znění SINIGELRINIS (např. Sijarić 2004, 14-24; 2014, 36-41), ani u obdobně datované luxusní zbraně ze sbírek Vojenského historického ústavu v Praze, která na jedné ploše čepele nese tř̌i skupiny tř́i liter $I$ a na druhé ploše čepele pak iniciálovou inskripci ve znění SIGVINAIS (např. Wagner 1959; Děd-Klučina 2004, Hošek-Košta-Žákovský 2019, kat. č. 394). V tomto ohledu zaujímá mezi těmito zbraněmi zcela zvláštní pozici torzo meče Oakeshottova typu XII, N, 1 z přelomu 12. a 13. století, které je dnes součástí sbírek zbrojnice Státního zámku Žleby. Na jedné straně hrubí jeho čepele je ve žlábku situována výzdoba v podobě majuskulní litery $S$, od které se odvíjí vstřícné vlnovky o celkem osmi vrcholech. Na ně navazuje berličkový kříž, po kterém opět pokračuje vstřícná vlnovka, tentokráte se sedmi vrcholy. Celá výzdoba je zakončena dalším majuskulním písmenem $S$. $\mathrm{Na}$ druhé straně hrubí je výzdoba tvořena berličkovým křížem, od kterého vychází celkem 19 příčných linií, či majuskulních liter $I$. Na tento motiv navazuje majuskulní litera $S$, a od něj dále pokračuje výzdoba v podobě 19 příčných linií či liter $I$. Celá výzdoba je opět zakončena berličkovým křižem. Výzdoba čepele je ještě po obou stranách čepele doplněna o drobné lilie pod ukončením žlábků na tenčí (obr. 14:c, Hošek-Košta-Žákovský 2019, kat. č. 428). Je ovšem otázka, zda opravdu lze na této zbrani linie interpretovat jako 38krát opakované jméno Spasitele. Přítomnost liter $S$ by této eventualitě spíše nasvědčovala. Takto koncipovaná výzdoba nám prozatím není známa. Asi nejblíže k ní má výzdoba blíže nelokalizovaného meče z přelomu 12. a 13. století ze sbírek Bayerisches Armeemuseum v Ingolstadtu, na jehož jedné ploše čepele se stř́idá množství liter $I$ a $N$ a na druhé ploše je pak dlouhá řada příčných linií, interpretovatelných znovu jako litera $I$, kterou na obou koncích uzamykají geometrické motivy (Geibig 1991, kat. č. 60 , tab. 43 ).

Těsnou spojitost liter $S$ a $I$ dokládá mimo jiné i fakt, že často tvoří na čepelích středověkých mečů různé formy ligatur (např. Wagner a kol. 2009, 42). To je ostatně i př́ípad studovaného meče z Hoštic, kde je litera $I$ poměrně netradičním způsobem vepsána do litery $S$ (obr. 3, 10, 12). Na mečích z průběhu 11.-13. století takto koncipovaná ligatura nebyla prozatím evidována. Na pozdějších dlouhých mečích z průběhu 14. století se objevují také velmi sporadicky. V podstatě známe prozatím pouhé dva exempláře. Jeden z nich představuje dlouhý meč Oakeshottova typu XVIa, -, 1, který byl vytažen z koryta řeky Dunaje u Visegrádu (Głosek 1984, kat. č. 450), a druhý pak blíže nelokalizovaný dlouhý meč Oakeshottova typu XIIIa, J, 2 ze sbírek Zemaljski muzej Bosne a Hercegovine v Sarajevu (Sijarić 2004, 50-57; 2014, 98-101).

Můžeme tedy shrnout, že objevený nápis řadí románský meč z Hoštic $\mathrm{k}$ nepočetné skupině zbraní s obdobnou iniciálovou inskripcí. Kombinace liter $S O S$ či $O S O$ se na zbraních objevuje v poměrně dlouhém časovém úseku 12. až první poloviny 14. století, takže lze celkem spolehlivě konstatovat, že se nejedná o produkty jedné dílny. Samotnou inskripci lze nejspíše považovat za invokační frázi, která se mohla inspirovat soudobými církevními texty, především texty ze soudobých misálů a žaltářů. Tato eventualita je i s ohledem na ostatní typy iniciálových inskripcí využitých při výzdobě mečů velmi pravděpodobná, přestože bychom přesné znění této fráze ve zmíněných textech jen marně hledali. V podstatě existují tři interpretace těchto iniciálových inskripcí. Navrhovaná čtení Sancta O Sancta (Wegeli 1902-1905, 223-224; Bruhn Hoffmeyer 1954, 117-118; Dufty 1974, 14) a Salus Omnium Salus (nарř. Кирпичников 1966, 56) jsou dnes spíše nahrazena pravděpodobnější interpretací jako Salvator Omnipotens Salvator, případně Omnipotens Salvator Omnipotens (např. Głosek 1973, 65; 1984, 111-112; Aleksić 2007, 121; Sijarić 2014, 63; Marek 2017, 108). Na meči z Hoštic je tato kombinace prozatím zcela ojediněle modifikována doplněním o literu $I$, takže celý nápis $(\mathrm{SI}) \mathrm{O}(\mathrm{SI})$ / O(SI)O bychom mohli číst jako Salvator Jesus Omnipotens Salvator Jesus / Omnipotens Salvator Jesus Omnipotens. 
Jedná se tedy s největší pravděpodobností o invokaci ústřední postavy křest’anského náboženství, která měla majiteli zbraně zabezpečit jeho ochranu a pomoc v samotném boji. Účinek nápisu měl být nepochybně záměrně umocněn tím, že na každé ploše čepele se objevují pouze tři litery, počítáme-li tedy ligaturu SI za jedno písmeno, přičemž každé z písmen se na meči objevuje rovněž třikrát. Tato trichotomie jistě měla znásobovat symbolický účinek inskripce na majitele zbraně. Bez významu není rovněž fakt, že se v obou prŕípadech jedná o dokonalý palindrom. Poněkud složitější je otázka působení takto zdobené a sakralizované zbraně na širší publikum. Vzhledem k tomu, že nápis byl tvořen poměrně tenkými, takřka vlasovými liniemi, které navíc nebyly inkrustovány kontrastním kovem, nýbrž cínem, musela inskripce na vyleštěné čepeli být jen velmi špatně zřetelná. To by mohlo naznačovat, že případná symbolická komunikace probíhala v prvotní rovině pouze mezi zbraní a jejím majitelem a nebyla určena k obecnému sdílení.

\section{Závěr}

Zbraň z Hoštic, kterou lze klasifikovat jako meč typu XII, B, 1, byla vyrobena někdy v průběhu 12. století, přičemž její čepel je tvořena ocelovým pláštěm, který obaluje měkčí jádro, což je konstrukce navazující na starší koncept čepelí svařených z vícera prutů. Takováto změna konstrukce by mohla naznačovat nástup mechanizace (padacích bucharů poháněných vodní silou) při výrobě mečových čepelí ve sledovaném období. To by ukazovalo na spíše západní původ zbraně či alespoň čepele, nebot's hamry se na našem území ve větším měřítku můžeme setkat až značně později (např. Kreps 1976, 5-9). Hypotéza o mechanizaci výroby čepelí by vysvětlovala postupný nárůst produkce mečů a s ním spojený pokles jejich ceny $\mathrm{v}$ období vrcholného a pozdního středověku, v jehož průběhu se ze symbolu vysokého společenského statusu stala běžná výbava bojovníka. $\mathrm{V}$ př́ípadě meče $\mathrm{z}$ Hoštic však máme před sebou zcela jistě zbraň, která ve své době neplnila jen praktickou funkci, ale nepochybně byla i jakýmsi statutárním symbolem, který reprezentoval a v obecně čitelné rovině vyjadřoval prŕslušnost svého majitele k tehdejší společenské elitě. Symbolickou a částečně sakralizovanou funkci studovaného meče zdůrazňuje i přítomnost specifické iniciálové inskripce na čepeli, kterou lze nejspíše číst jako Salvator Iesus Omnipotens Salvator, respektive Omnipotens Salvator Iesus Omnipotens, a která jistě měla pro majitele zbraně hluboký význam a plnila nepochybně i apotropaickou funkci.

Interpretace nálezových okolností, respektive př́íčin archeologizace studované zbraně, je však značně problematická, což úzce souvisí především s nedostatečným poznáním osídlení zkoumaného regionu v průběhu 11.-13. století. Nalezená zbraň tak představuje i výrazný pramen k dějinám osídlení sledované oblasti, přestože jej nelze za dnešního stavu poznání spojit s některým z výše uvedených sídel.

Výroba této zbraně totiž značně předcházela prvním písemným zmínkám, které se k daným sídlům vážou. I když nelze zcela vyloučit možnost, že meč mohl být využíván i mnoho desítek let po svém vykování, at' již ve své primární funkci coby zbraň, či ve funkci symbolického předmětu. Meč byl totiž až do 14. století důležitým čitelným a obecně srozumitelným symbolem sociální komunikace, protože veřejně demonstroval a prokazoval př́slušnost jedince ke konkrétní a výlučné skupině hierarchicky uspořádané společnosti a zdůrazňoval její jedinečnost a vymezoval tuto skupinu vůči ostatním. Meče tudíž mohly často představovat i jistý druh memorabilie, respektive rodinné památky. Tak je např́íklad některými historiky interpretována jedna zmínka z Kosmovy kroniky, která ke konci 11. století pojednává o vlivném předákovi za vlády Vratislava II. Benedovi, který zřejmě uchovával meč se zlacenou rukojetí jako památku na svého významného předka (např. Hrdina 1950, 128; Wihoda 2007, 21; Šimůnek 2013, 298).

V každém případě lze nález meče interpretovat jakožto nahodilou ztrátu související s provozem na síti dnes již zaniklých komunikací. Nelze ani vyloučit, že zbraň nemá žádný bližší vztah k danému regionu, nebot' ji zde mohl ztratit člověk, který tímto místem pouze nahodile projižděl. I tak tento meč představuje důležitý pramen, který prokazuje přítomnost př́islušníka tehdejších elit, byt' třeba jen epizodickou, v daném prostoru. Lze tak jen spekulovat o tom, za 
jakých okolností majitel tuto zbraň pozbyl, přestože nelze pochybovat o tom, že o její nalezení či opětovné vyzvednutí usiloval. Vždyt’ taková luxusní zbraň, jejíž původ lze na základě technologie výroby čepele i formy inskripce hledat hypoteticky někde na západ od našeho území, musela ve své době představovat značné jmění. Tím se meč z Hoštic řadí k velmi početné skupině mečů $\mathrm{s}$ obdobnými nálezovými okolnostmi, které v podstatě představují společně $\mathrm{s}$ nálezy ve vodních tocích nejčastější nálezové prostředí vrcholně a pozdně středověkých mečů. U těchto nálezů je však případná bližší interpretace př́ičin jejich archeologizace většinou zcela nemožná či přinejmenším výrazně ztížená (např. Žákovský-Hošek-Sedláčková 2013, 260-261; HošekKošta-Žákovský 2019, 35-40).

Studie vznikla s institucionální podporou na dlouhodobý koncepční rozvoj výzkumné organizace RVO: 68081758 - Archeologický ústav AV ČR, Brno, v. v. i.

\section{Literatura}

ALEKSIĆ, M., 2007: Medieval Swords from Southeastern Europe. Material from 12th to 1th Century. Belgrade.

ALEXANDER, D. G., 1985: European Swords in the Collections of Istanbul. Part I. Swords from the Arsenal of Alexandria, Waffen- und Kostümkunde 27, 81-118.

ANTEINS, A., 1964: Damascētie un ierakstu zobeni Latvijā un to asmeņu tehnologija, Par tehnikas vēsturi Latvijas PSR VI, 65-95.

BÁRTA, P.-HLOŽEK, M., 2018: Průzkum a konzervace železného meče z Kroměřížska, Fórum pro konzervátory-restaurátory 2018, 3-6.

BIBORSKI, M.-STĘPIŃSKI, J.-ŻABIŃSKI, G., 2009: Nowe badania nad Szczerbcem - mieczem koronacyjnym królów polskich, Studia Waweliana XIV, 235-252.

- 2011: Szczerbiec (the jagged sword) - the coronation sword of the kings of Poland, Gladius XXXI, 93-148. BRUHN HOFFMEYER, A., 1954: Middelalderens tveæggede sværd I-II. København.

ČERVINKA, I. L., 1927: Zapomenuté hrady a tvrze Moravské, Časopis Vlastivědného spolku musejního v Olomouci XXXIX, 88-95.

- 1929: Zapomenuté hrady a tvrze Moravské III, Časopis Vlastivědného spolku musejního v Olomouci XLI, $153-160$.

DĚD, J.-KLUČINA, P., 2004: Identifikace matriálů a zdobné techniky hlavice románského meče, Koroze a ochrana materiálu 48, č. 3, 52-57.

DEMO, Ž., 1984: Srdnjovjekovni mačevi u Muzeju grada Koprivnice, Vjesnik Arheološkog muzeja u Zagrebu 16-17, 211-240.

DOSTÁL, B., 1966: Slovanská pohřebiště ze střední doby hradištní na Moravě. Praha.

DUFTY, A. R., 1974: European Swords and Daggers in the Tower of London. London.

FIŠER, Z., 1976: Pravěk Kroměřižska. Soupis. Nepubl. rukopis disertační práce na UJEP Brno.

FORRER, R., 1918-1920: Romanischer Schwertinschriften auf einem Tragaltar in Paderborn, Zeitschrift für historische Waffenkunde VIII, 255-256.

GASPARI, A., 2017: Reka Ljubljanica in fenomen vodnih najdb srednjeveških meče viz obdobja od 11. do 15. stoletja, Arheološki vestnik 68, 387-438.

GAY, V., 1887: Glossaire archéologique du moyen age et de la renaissance. Tome premier A-Guy. Paris.

GEIBIG, A., 1990: ,SININIS‘, an interesting blade inscription on a Medieval sword, Congress report IAMAM XII, 125-127.

- 1991: Beiträgezur morphologischen Entwicklung des Schwertes im Mittelalter. Eine Analyse des Fundmaterials vom ausgehenden 8. bis zum 12. Jahrhundert aus Sammlungen der Bundesrepublik Deutschland. Neumünster.

- 1996: Gefärlich und schön. Eine Auswahl historischer Waffen aus den Bestände der Kunstsammlungen de Veste Coburg. Coburg. 
GŁOSEK, M., 1973: Znaki i napisy na mieczach średniowiecznych w Polsce. Wrocław - Warszawa Kraków - Gdańsk.

- 1984: Miecze środkowoeuropejskie z X-XV w. Warszawa.

GŁOSEK, M.-MAKIEWCIZ, T., 2007: Two incrusted medieval swords from Zbaszyn, Lubusz voivodship, Gladius XXVII, 137-147.

GŁOSEK, M.-NADOLSKI, A., 1970: Miecze średniowieczne z ziem polskich. Łódź.

HOSÁK, L., 1938: Historický místopis země Moravskoslezské. Praha.

- 1967: Historický místopis Moravy a Slezska v letech 1848-1960. Úvodní svazek. Ostrava.

HOSÁK, L.-ŠRÁMEK, R., 1970: Místní jména na Moravě a ve Slezsku I (A-L). Praha.

- 1980: Místní jména na Moravě a ve Slezsku II (M-Ž). Praha.

HOŠEK, J.-KOŠTA, J., 2014: Early Medieval Swords from Mikulčice. Studien zum Burgwall von Mikulčice band X. Brno.

HOŠEK, J.-KOŠTA, J.-ŽÁKOVSKÝ, P., 2019: Ninth to mid-sixteenth century swords from the Czech Republic in their European context. Part I. The finds. Prague - Brno.

- 2020: Ninth to mid-sixteenth century swords from the Czech Republic in their European context. Part II. Swords of medieval and early renaissance Europe as a technological and archaeological source. Prague Brno (v tisku).

HRDINA, K., ed., 1950: Kosmova Kronika česká. Praha.

CHODYŃSKI, A. R.-ŻABIŃSKI, G., 2011: Medieval swords from the Castle museum in Malbork and the Polish national museum in Szczecin, The Journal of the Arms and armour society XX, 113-138.

CHYBOVÁ, H., 1986: Záchranný výzkum mladohradištního pohřebiště ve Zborovicích, Studie Muzea Kroměřížska 86, 3-24.

- 1989: Záchranný výzkum středohradištních kostrových hrobů v Litenčicích (okr. Kroměříž), PV $1986,63$.

- 1990: Rettungsgrabung des mittelburgwallzeitlichen Gräberfeldes in Litenčice im Jahre 1987 (Bez. Kroměříž), PV 1987, 60.

- 1993: Fortsetzung der erforschung mittelburgwallzeitlicher gräber in Litenčice (Bez. Kroměříž), PV 1989, 77-78.

- 1998: Pravěké a slovanské osídlení Kroměřížska. Průvodce archeologickou expozicí a sbírkami Muzea Kroměřížska. Kroměříž.

KOČÍ, J.-VONDRUŠKA, V., edd., 1989: Památky národní minulosti. Katalog historické expozice Národního muzea v Praze v Lobkovickém paláci. Praha.

KOŠTA, J. a kol., 2014: Košta, J.-Šteffl, J.-Hošek, J.-Lutovský, M., Raně středověký meč z Píseckých hor An early medieval sword from the Písek mountains, ASČ 18, 299-318.

KREPS, M., 1976: Hamry v českém a moravském železářství. Praha.

KUCYPERA, P.-KURASIŃSKI, T.-PUDŁO, P., 2011: Problem rozwoju jednolitych głowic mieczowych między połową IX a połową XIII w. In: Cum Arma per Aeva. Uzbrojenie indywidualne na przestrzeni dziejów (Kucypera, P.-Pudło, P., edd.), 74-90. Toruń.

KURASIŃSKI, T.-PUDŁO, P., 2009: Jeszcze o Bałtyjskiej (?) produkcji wczenośredniowiecznych mieczy grupy T. In: Gospodarka ludów Morza Bałtyckiego. Tom I. Starożytność i śrdniowiecze (Bogacki, M.Franz, M.-Pilarczyk, Z., edd.), 256-317. Toruń.

LABUDA, M., 2016: Chladné zbrane 10.-16. storočia pochádzajúce z rieky Váh. Nepubl. diplomová práce na ÚAM FF MU Brno.

MALINOWSKI, T., 1975: Łotewskie analogie do polskich mieczów średniowiecznych, Kwartalnik Historii Kultury Materialnej XXIII, 115-118.

MAPELLI, C.-NICODEMI, W.-RIVA, R. F., 2007: Microstructural investigation on a medieval sword produced in 12th century AD, ISIJ International 47, 1050-1057. https://doi.org/10.2355/isijinternational.47.1050

MAREK, L., 2008: Broń biała na Śląsku. XIV-XVI wiek. Wrocław.

- 2014: Europejski styl. Militaria z Elbląga i okolic. Wrocław.

- 2017: Średniowieczne uzbrojenie Europy łacińskiej jako Ars Emblematica. Wratislavia Antiqua 22. Wrocław.

MICHALAK, A., 2007: „A grodzianie [...] wyszli naprzeciw z dobytymi mieczami...“ Więcej o występowaniu mieczy na Środkowym Nadodrzu w średniowieczu, Archeologia Środkowego Nadodrza V, 215-240. 
- 2018: Kolejna głowica miecza w typie B ze Środkowego Nadodrza. Obserwacje na marginesie znaleziska z Niesulic, pow. Świebodziński, Acta Militaria Mediaevalia XIV, 229-236.

-2019: Arma confinii. Przemiany późnośredniowiecznej broni na rubieżach Śląska, Wielkopolski, Brandenburgii i Łużyc. Zielona Góra.

MÜLLER, H.-KÖLLING, H., 1984: Europäische Hieb- und Stichwaffen aus der Sammlung des Museums für Deutsche Geschichte. Berlin.

NEKUDA, V., 1961: Zaniklé osady na Moravě v období feudalismu. Brno.

NEKUDA, V.-UNGER, J., 1981: Hrádky a tvrze na Moravě. Brno.

OAKESHOTT, R. E., 1951: Some Medieval Sword-Pommels: An Essay in Analysis, Journal of the British Archaeological Association 14, 47-62. https://doi.org/10.1080/00681288.1951.11894598

- 1960: The Archaeology of Weapons. Arms and Armour from Prehistory to the Age of Chivalry. London.

- 1964: The Sword in the Age of Chivalry. New York - Washington.

- 2002: Records of the Medieval Sword. Woodbridge.

PEIRCE, I., 2002: Swords of the Viking Age. Woodbridge.

PERTL, M., 1991: Středověké zbraně ze sbírek Státního hradu Švihova, SSPS 2, 193-199.

- 1992: Archeologické památky ze zbrojnic českých památkových objektů - Archäologische Denkmäler in den Zeughäusern der böhmischen Baudenkmäler, AH 17, 403-410.

PEŘINKA, F. V., 1910: Vlastivěda moravská II. Místopis. Zdounecký okres. Brno.

PINTER, Z.-K., 2007: Spada şi sabia medievală în Transilvania şi Banat (secolele IX-XIV). Sibiu.

PLAČEK, M., 2001: Ilustrovaná encyklopedie moravských hradů, hrádků a tvrzí. Praha.

POST, P., 1918-1920: ENRICUS DUX?, Zeitschrift für historische Waffenkunde VIII, 246-250.

PTÁČKOVÁ, M.-HIMMELOVÁ, Z.-USTOHAL, V., 1994: Meč z brněnského Špalíčku intarzovaný cínem, Archeologia technica 9, 16-29.

RAGETH, J., 2000: Ein mittelalterliches Schwert mit Zauberspruch von Tschlin-Vinadi GR, Archäologie der Schweiz XXIII, 128-130.

ROYT, J.-ŠEDINOVÁ, H., 1998: Slovník symbolů. Kosmos, př́roda a člověk v křest’anské ikonografii. Praha.

RUTTKAY, A., 1971: Dva stredoveké meče s nápismi zo Slovenska, AR XXIII, 163-168.

- 1975: Waffen und Reiterausrüstung des 9. bis zur ersten Hälfte des 14. Jahrhunderts in der Slowakei I, SlArch XXIII, 119-216.

- 1976: Waffen und Reiterausrüstung des 9. bis zur ersten Hälfte des 14. Jahrhunderts in der Slowakei II, S1Arch XXIV, 245-395.

- 1978: Umenie kované v zbraniach. Bratislava.

SCALINI, M., ed., 2007: A bon droyt. Spade di uomini liberi cavalieri e santi. Milano.

SELUCKÁ, A., 2016: Až na kov! Záchrana sbírek poškozených požárem hradu Krásná Hôrka. Brno.

SCHMID, W. M., 1918-1920: Frühmittelalterliche Schwertinschriften, Zeitschrift für historische Waffenkunde VIII, 244-246.

SCHNEIDER, H.-STÜBER, K., 1980: Waffen im Schweizerischen Landesmuseum. Griffwaffen I. Zürich.

SCHOKNECHT, U., 1969: Eiserne Schwerter mit Inschrift aus Mecklenburg, Ausgrabungen und Funde XIV, 212-217.

SCHRÖTER, E., 1969: Ein mittelalterlicher Schwertfunde bei Rübeland im Harz, Ausgrabungen und Funde $14,41-43$.

SIJARIĆ, M., 2004: Mačevi 10.-15. stoljeća iz Bosne i Hercegovine. Sarajevo.

- 2014: Hladno oružje iz Bosne i Hercegovine u arheologiji razvijenog i kasnog srednjeg vijeka. Sarajevo.

SKUTIL, J., 1941: Morkovsko v pravěku. Morkovice.

STANKUS, J., 1970: Kalavijų ir ietigalių gamybos technologija Lietuvoje IX-XIII amžiais, Lietuvos TSR Mokslu Akademijos darbai - A serija 2(33), 113-130.

ŠIMŮNEK, R., 2013: Reprezentace české středověké šlechty. Praha.

ŠNAJDROVÁ, E., 2014: Arma ofensiva et defensiva. Historické zbraně a zbroj ze sbírky Národního muzea. Praha.

ULLMANN, K., 1958: Schwertsegen - Schwertzauber, Zeitschrift des Vereins für Lübeckische Geschichte und Altertumskunde XXXVIII, 157-163. 
VAVERKOVÁ, Z., 1992: Hluboká. Zbrojnice. Praha.

WAGNER, E., 1959: SIGVINAIS - románský meč, ČNM - Vědy společenské CXXVIII, 125-132.

- 1993: Sečné a bodné zbraně. České Budějovice.

WAGNER, T. G. a kol., 2009: Wagner, T. G. -Worley, J.-Blennow, A. H.-Beckolmen, G., +INNOMINEDOMINI+ Medieval Christian invocation inscriptions on sword blades, Waffen- und Kostümkunde 51, $11-52$.

WEGELI, R., 1902-1905: Inschriften auf mittelalterlichen Schwertklingen, Zeitschrift für historische Waffenkunde III, 261-268.

WIHODA, M., 2007: Kníže a jeho věrní. Kosmas o světě předáků a urozených. In: Šlechta, moc a reprezentace ve středověku (Nodl, M.-Wihoda, M., edd.), 11-29. Praha.

WILliAMS, A., 2012: The Sword and the Crucible. A History of the Metallurgy of European Swords up to the 16th Century. Leiden - Boston.

ŻABIŃSKI, G., 2017: A late medieval sword from the river Wisła near Gniew (Mewe) in Pomerelia, Fasciculi Archaeologiae Historicae XXX, 163-179.

ŻABIŃSKI, G.-STĘPIŃSKI, J.-BIBORSKI, M., 2014: Technology of Sword Blades from the La Tène Period to the Early Modern Age. The case of what is now Poland. Oxford.

ŻYGULSKI, Z., jr., 2008: „Szczerbiec“. In: Urbs celeberrima. Księga pamiątkowa na 750-lecie lokacji Krakowa (Grzybkowski, A.-Żygulski jr., Z.-Grzybkowska, T., edd.), 310-355. Kraków.

ŽÁKOVSKÝ, P.-HOŠEK, J.-SEDLÁČKOVÁ, L., 2013: Meče 11.-13. století z území Moravy - Swords from the 11th-13th Centuries on Moravian Territory, AH 38, 219-270.

ДРБОГЛАВ, Д. А., 1984: Загадки латинских клейм на мечах IX-XIV веков. Классификация, датировка и чтение надписей. Москва.

КИРПИЧНИКОВ, А. Н., 1966: Древнерусское оружие І. Мечи и сабли IX-XIII вв. Москва - Ленинград. ЛЕНЦъ, Е., 1908: Императорский Ермитажъ. Указатель отдђленія среднихъ въковъ и епохи возрожденія. Часть І. Собраніе оружія. Санкт Петербургъ.

\section{Zusammenfassung}

\section{Ein romanisches Schwert aus Hoštice in der Region Kroměříž}

Im Jahr 2016 wurde im Rahmen einer gesteuerten systematischen Detektorprospektion eines Waldgebietes im Westen der Region Kroměříž der Solitärfund eines romanischen Schwertes gemacht, das als Schwerttyp XII, B, 1.klassifiziert werden kann. Die Waffe wurde irgendwann im Laufe des 12. Jahrhunderts hergestellt, wobei ihre Klinge aus einer Stahlummantelung besteht, die einen weicheren Kern umhüllt, was eine Konstruktionweise ist, die an das ältere Konzept von aus mehreren Stäben verschweißten Klingen anknüpft. Eine solche Konstruktionsänderung könnte auf das Aufkommen einer Mechanisierung (wassergetriebene Fallhämmer) bei der Herstellung von Schwertklingen im beobachteten Zeitraum hindeuten. Das würde eher für eine westliche Herkunft der Waffe bzw. zumindest der Klinge sprechen, da wir in den Ländern Böhmens Hammerwerken erst bedeutend später in größerem Maßstab begegnen können (z.B. Kreps 1976, 5-9). Die Hypothese von einer mechanisierten Herstellung von Klingen würde den allmählichen Produktionszuwachs von Schwertern und ihren damit verbundenen Preisrückgang während des Hoch- und Spätmittelalters erklären, in dessen Verlauf aus einem hohen gesellschaftlichen Statussymbol ein gängiger Ausstattungsgegenstand eines Kriegers wurde. Im Falle des Schwertes aus Hoštice haben wir es jedoch sicherlich mit einer Waffe zu tun, die seinerzeit nicht nur eine praktische Funktion erfüllte, sondern zweifellos auch ein gewisses Statussymbol war, das Repräsentationsfunktion hatte und auf allgemeiner Ebene die Zugehörigkeit ihres Besitzers zur damaligen gesellschaftlichen Elite zum Ausdruck brachte. Die symbolische und teilweise sakralisierte Funktion des untersuchten Schwertes wird auch durch das Vorhandensein einer speziellen Initialinschrift betont, die höchstwahrscheinlich als Salvator Iesus Omnipotens Salvator, bzw. 
als Omnipotens Salvator Iesus Omnipotens gelesen werden kann und für den Besitzer der Waffe sicherlich eine tiefe Bedeutung hatte und zweifellos auch eine apotropäische Funktion erfüllte.

Die Interpretation der Fundumstände, bzw. die Ursachen für die Archäologisierung der untersuchten Waffe ist jedoch sehr problematisch, was vor allem eng mit den unzureichenden Kenntnissen über die Besiedelung der untersuchten Region im Verlauf des 11.-13. Jahrhunderts zusammenhängt. Die gefundene Waffe stellt somit auch eine markante Quelle zur Besiedelungsgeschichte des beobachteten Gebietes dar, obwohl sie beim heutigen Kenntnisstand nicht mit einem der in Betracht kommenden Sitze in Verbindung gebracht werden kann.

Die Herstellung dieser Waffe liegt nämlich beträchtlich vor den ersten schriftlichen Erwähnungen, die mit diesen Sitzen zusammenhängen. Obwohl nicht völlig ausgeschlossen werden kann, dass das Schwert auch viele Jahrzehnte nachdem es geschmiedet worden war benutzt wurde, und zwar sei es nunmehr in seiner primären Funktion als Waffe, oder in der Funktion eines symbolischen Gegenstandes. Das Schwert war nämlich bis zum 14. Jahrhundert ein wichtiges, lesbares und allgemeinverständliches Symbol der sozialen Kommunikation, da es öffentlich die Zugehörigkeit eines Individuums zu einer konkreten und exklusiven Gruppe der hierarchisch geordneten Gesellschaft demonstrierte und nachwies, wodurch dessen Einzigartigkeit hervorgehoben wurde und diese Gruppe gegenüber anderen abgrenzte. Schwerter konnten nämlich häufig auch eine gewisse Art Memorabilia, bzw. Familienerinnerungsstücke darstellen. So wird von einigen Historikern beispielsweise eine Erwähnung in der Chronik des Cosmas interpretiert, die gegen Ende des 11. Jahrhunderts über einen einflussreichen Landesherrn unter der Herrschaft von Vratislav II. namens Benedov berichtet, der offenbar ein Schwert mit goldenem Griff zur Erinnerung an einen seiner bedeutenden Vorfahren aufbewahrte (z.B. Hrdina 1950, 128; Wihoda 2007, 21; Šimůnek 2013, 298).

In jedem Fall kann der Fund des Schwertes als eine Art Zufallsverlust interpretiert werden, der mit dem Betrieb auf dem heute bereits verschwundenen Verkehrswegenetz zusammenhing. Man kann auch nicht ausschließen, dass die Waffe keinen näheren Bezug zur gegebenen Region hat, da sie jemand dort verloren haben konnte, der diesen Ort lediglich zufällig passierte. Auch so stellt dieses Schwert eine wichtige Quelle dar, welche die Präsenz eines Angehörigen der damaligen Eliten in dem gegebenen Raum nachweist, sei es auch nur eine episodenhafte. Somit kann man nur Spekulationen darüber anstellen, unter welchen Umständen der Besitzer dieses Schwert verloren hat, obwohl kein Zweifel daran bestehen kann, dass er sich darum bemüht hat, es wiederzufinden bzw. es sich wieder zu holen. Eine solche Luxuswaffe, deren Herkunft aufgrund der Herstellungstechnologie der Klinge und auch der Form der Inschrift nach hypothetisch irgendwo im Westen unseres Gebietes gesucht werden kann, muss seinerzeit doch ein beträchtliches Vermögen dargestellt haben. Dadurch reiht sich das Schwert aus Hoštice unter die sehr zahlreiche Gruppe von Schwertern mit vergleichbaren Fundumständen, die im Grunde genommen zusammen mit in Wasserläufen gemachten Funden die häufigsten Fundkontexte von hoch- und spätmittelalterlichen Schwertern darstellen. Bei diesen Funden ist eine zutreffende nähere Interpretation der Ursachen ihrer Archäologisierung meistens völlig unmöglich, bzw. zumindest sehr schwierig (z.B. Žákovský-Hošek-Sedláčková 2013, 260-261; Hošek-Košta-Žákovský 2019, 35-40).

Die Studie wurde im Rahmen der institutionellen Förderung der langfristigen konzeptionellen Entwicklung der Forschungsorganisation (RVO: 68081758) erstellt. 
Mgr. Petr Žákovský, Ph.D., Archeologický ústav AV ČR, Brno, v. v. i., Čechyňská 363/19, 60200 Brno, Česká republika,zakovsky@arub.cz

Ing. Jiří Hošek, Ph.D., Archeologický ústav AV ČR, Praha, v. v. i., Letenská 4, 11801 Praha 1, Česká republika,hosek@arup.cas.cz

Mgr. Patrick Bárta, Archeologický ústav AV ČR Brno, v. v. i., Čechyňská 363/19, 60200 Brno, Česká republika,barta@arub.cz

Mgr. Adam Fojtík, Ústav archeologické památkové péče Brno, v. v. i., Kaloudova 1321/30, 61400 Brno, Česká republika,adam.fojtik@uapp.cz

Mgr. Miroslav Popelka, Ústav archeologické památkové péče Brno, v. v. i., Kaloudova 1321/30, 61400 Brno, Česká republika,popelka@uapp.cz 
